\title{
Addressing fuel recycling in solid oxide fuel cell systems fed by alternative fuels
}

\section{Rokni, Masoud}

\section{Published in:}

Energy

Link to article, DOI:

10.1016/j.energy.2017.03.082

Publication date:

2017

Document Version

Peer reviewed version

Link back to DTU Orbit

\section{Citation (APA):}

Rokni, M. (2017). Addressing fuel recycling in solid oxide fuel cell systems fed by alternative fuels. Energy, 137, 1013-1025. https://doi.org/10.1016/j.energy.2017.03.082

\section{General rights}

Copyright and moral rights for the publications made accessible in the public portal are retained by the authors and/or other copyright owners and it is a condition of accessing publications that users recognise and abide by the legal requirements associated with these rights.

- Users may download and print one copy of any publication from the public portal for the purpose of private study or research.

- You may not further distribute the material or use it for any profit-making activity or commercial gain

- You may freely distribute the URL identifying the publication in the public portal

If you believe that this document breaches copyright please contact us providing details, and we will remove access to the work immediately and investigate your claim. 


\title{
Addressing Fuel Recycling in Solid Oxide Fuel Cell Systems Fed by Alternative Fuels
}

\author{
M. Rokni \\ Department of Mechanical Engineering \\ Institution of Thermal Energy Systems, Copenhagen, Denmark \\ e-mail:MR@mek.dtu.dk
}

\begin{abstract}
An innovative study on anode recirculation in solid oxide fuel cell systems with alternative fuels is carried out and investigated. Alternative fuels under study are ammonia, pure hydrogen, methanol, ethanol, DME and biogas from biomass gasification. It is shown that the amount of anode off-fuel recirculation depends strongly on type of the fuel used in the system. Anode recycling combined with fuel cell utilization factors have an important impact on plant efficiency, which will be analysed here. The current study may provide an in-depth understanding of reasons for using anode off-fuel recycling and its effect on plant efficiency. For example, it is founded that anode recirculation is not needed when the plant is fed by ammonia. Further, it is founded that when the system is fed by pure hydrogen then anode recirculation should be about $20 \%$ of the off-fuel if fuel cell utilization factor is $80 \%$. Furthermore, it is founded that for the case with methanol, ethanol and DME then at high utilization factors, low anode recirculation is recommended while at low utilization factors, high anode recirculation is recommended. If the plant is fed by biogas from biomass gasification then for each utilization factor, there exist an optimum anode recirculation at which plant efficiency maximizes.
\end{abstract}

\section{Keywords}

SOFC, fuel cell, alternative fuels, anode recirculation, methanol, ethanol, ammonia, biogas.

\section{INTRODUCTION}

With an ever increasing demand for more efficient power production and distribution, some main research and development for the electricity production is identified as efficiency enchantments and pollutant reduction, especially carbon dioxide among others. Alternative fuels have also been recognized as potential element in decreasing emissions locally such final at end users.

Solid Oxide Fuel Cells (SOFCs) are recognized as one of the most promising types of fuel cells, particularly in terms of energy production. Besides pure hydrogen they can be fed variety of fuels such as Natural Gas (NG), ethanol, Di Methyl Ether (DME), methanol and syngas from gasification of biomass or municipal waste. They are expected to produce clean electrical energy at high conversion rates with low noise and low pollutant emissions [1]. They can tolerate sulphur compounds at concentrations higher than those tolerated by other types of fuel cells. Additionally, unlike in most fuel cells, carbon monoxide can be used as a fuel in SOFCs. Due to the above-mentioned advantages, SOFCs are considered to be a strong candidate for either hybrid systems or integration into currently deployed technologies. Therefore, SOFC plants have been the subject of many studies since the beginning of 90s. For 
example [2] showed that electrical efficacy of a hybrid plant consisting SOFC, gas turbine and steam turbine may reach about $70 \%$ which is encouraging to further investigate on such plants.

Numerous studies on SOFC based systems have been considered in the literature among them SOFC-gas turbines hybrid systems have extensively studied, for example the study of [3] shows that plant efficiency reaches about $60 \%$ at full lad while its part-load (until 50\%) efficiencies are also above $50 \%$. In the study of [4], the net efficiency of a SOFC plant was calculated to be about 28-29\% when it is fed by biogas from biomass gasification. A study on biogas (assumed to be available in the gas grid without providing the source) fuelled SOFC micro-CPH in [5] showed that an overall CHP efficiency of about $80 \%$ is achievable for single-family detached dwellings. In another study carried out in [6], it was concluded that a SOFC plant fed by biogas from organic wastes may reaches electrical efficiencies of about $34 \%$ at approximately 55\% utilization factor. Biogas from wastewater treatment facilities was used in the study of [7] to estimate electrical efficiency of a SOFC plant. The study showed that plant efficiency would be about $41 \%$ if the utilization factor was selected to be $65 \%$. A study on syngas from municipal waste gasification carried out in [8] showed that plant efficiency of such integrated gasification-SOFC plant approaches about $43 \%$ with utilization factor of about $80 \%$. These are some examples of many that have been explored by researchers for utilization of waste to energy in sustainable modern societies.

SOFC fed by different fuels have also studied by many researchers. In the study of [9], the net efficiency of a $2 \mathrm{~kW}_{\text {el }}$ SOFC plant was calculated to be about $55 \%$ when the fuel was methanol. If DME was used as fuel, then the study of [10] showed that the plant efficiency will be about $50 \%$. The study of [11] showed that plant net efficiency of about $53 \%$ is achievable when the fuel of SOFC was bioethanol. In [12] an ammonia fed SOFC integrating with gas turbine was studied and the results shown efficiencies close to 56\%. Comparison performance of SOFC plants fed by alternative fuels have also been studied in [13] in which a single general modelling approach was used for the investigation. This single modelling approach with the same simulating code was also evaluated to ensure accuracy of the modelling and methodology used in the present study as documented in [13].

Despite extensive studies on SOFC based power plants, investigations on anode recycle SOFC systems fed by NG is comparably limited. Anode off-fuel recycling (anode gas recycle) is essential in SOFC systems fed by NG in order to provide steam for the steam reforming reactions in a pre-reformer prior to the SOFC cells. Exclusively all studies on anode recycling are about carbon formation and carbon deposition in the pre-reformer of a natural gas (NG) feed SOFC stack. Most of these studies are on stack level and do not on investigate the effect of anode recycling on system level and plant performances. For example, the experimental studies of [14] showed that the limit for $\mathrm{O} / \mathrm{C}$ ratio (oxygen-carbon ratio) to avoid carbon formation depends on the purity of gas. Their study showed that the limit of $\mathrm{O} / \mathrm{C}$ ratio for carbon formation for nickel catalyst was between 0.9 and 1.0 for Russian natural gas and between 1.0 and 1.25 for Danish natural gas. If precious metal catalyst used, then the limit was between $0.5-0.75$ irrespectively of natural gas composition. The effects of SOFC anode recycle on catalytic diesel reforming and carbon formation was also studied in [15] experimentally. This study showed that anode recycle is more effective than reformer recycle when it comes to carbon formation in the reformer (off-fuel from SOFC, not reformate gas out of reformer). Steam recycling for internal methane (and/or natural gas) reforming in SOFCs to analyse the carbon deposition using computational fluid dynamic was used in [16]. This study showed also that anode recycling is need to decreases carbon formation when fuel is methane or natural gas. Electric power generation of $380 \mathrm{~W}$ SOFC stack fed by methane with and without and anode recycle was demonstrated in [17]. Their study showed that anode recycle increases stack efficiency by about $10 \%$ when anode 
recycle is used. It was reported in [18] that cell voltage could be improved by anode off-fuel recycle in solid oxide fuel cell fed by pure methane. The study was on a cell level (not system level) with distinguished conclusion. The study of [19] showed that anode recycling enables the operation of a SOFC stack at low fuel utilizations without sacrificing the electrical efficiency of the stack. The maximum electrical efficiency of $57 \%$ was reached at $60 \%$ fuel utilization when the fraction of recycled fuel was $66 \%$. If no anode gas recycling was applied then the maximum electrical efficiency was about $53 \%$ with about $77.5 \%$ fuel utilization.

Despite many studies on anode recycling and carbon formation, studies on anode off-fuel recycling on plant efficiency are very limited and exclusively all are about natural gas (and/or methane) fed fuel. No study on of-fuel recycling with alternative fuels is found in the open literature, which makes the basis of the current study. The effect of anode recycling on plant efficiency using different types of fuels is investigated here which is completely novel and has not been studies elsewhere. A single study with similar conditions and prerequisites will thus reveal the importance of off-fuel recirculation on plant performance when the fuel is an alternative fuel. The findings in the current study may help SOFC system developer on boosting their plant efficiencies when alternative fuels are used. All foundlings are new and have not been reported elsewhere.

\section{PLANT LAYOUT AND MODELLING METHODOLOGY}

Figure 1 displays a typical SOFC plant with natural gas and/or methane as fuel. A similar layout can also be seen in e.g. [1], [5] and [20]. Air is compressed and preheated in a cathode preheater (CP) before entering the cathode side of the fuel cell. Natural gas (and/or pure methane) is firstly reformed and then preheated in an anode preheater (AP) before entering the anode side of the fuel cell. Depending on the utilization factor, a portion of the feed fuel will leave the anode side without reacting inside the fuel cells. The remaining fuel (off-fuel) and air (off-air) is then sent to a burner for further combustion. The off-gases after the burner is used to preheat both incoming air and fuel into the fuel cell. In order to provide steam for the reformer some of the off-fuel is recycled which calls for anode recirculation (or off-fuel recirculation). Even though the main purpose of the off-fuel recirculation is to provide steam for the steam reforming but it will also improve stack efficiency since more fuel is reacted inside the cells and therefore more power will be generated (see e.g. [19]). On the other hand, since no external steam is provided to the steam reformer (during normal operation) then it will be important that steam-carbon-ratio (S/C-ratio) is approximately above 1.8 to avoid carbon deposition, which has a significant effect on the reformer performance and lifetime, see e.g. [5]. However, most of the researchers assumes the value of 2 to be on the safe side, such as in [5], [6], [21] and [22]. Note that it is generally believed that carbon deposition can be determined by S/C ratio but the experimental study of e.g. [23] shows that not only S/C but also the extent of equilibrium in the gas mixtures should be taken into account to control the carbon deposition (O/C ratio). However, as shown in the study of [24] carbon deposition is not an issue in SOFC fed by wood gas from biomass gasification.

Figure 1. General fuel cell plant with anode off-fuel recirculation. CP: Cathode Preheater, AP: Anode Preheater.

However, when changing the fuel into alternative fuels such as ammonia, pure hydrogen, methanol and ethanol then there is no problem on limiting the $\mathrm{S} / \mathrm{C}$ (or $\mathrm{O} / \mathrm{C}$ ) ratio if a prereformer is used (see e.g. the $\mathrm{C}-\mathrm{H}-\mathrm{O}$ ternary diagram in [5]). If biogas (from biomass gasification) is used, then there will be enough steam in the gas and such problem does neither exist, as discussed in [24]. For such alternative fuels the question will be if off-fuel recirculation 
is needed or not and if it is needed then how it will effect on plant performance. This is the basis of the present study, which is entirely new and not been studied elsewhere.

In this study, the thermodynamic results are obtained using the Dynamic Network Analysis (DNA) simulation tool (see, e.g., [25]), established at DTU since 1983. The program has continuously been developed to be generally applicable for different energy systems. It includes a component library, thermodynamic state models for fluids and standard numerical solvers for differential and algebraic equation systems. The component library contents models for heat exchangers, burners, turbo machinery, decanters, energy storages, valves and controllers, among many others. Figure 2 illustrates the calculation procedure used in the program.

\section{Figure 2. Calculation procedure.}

DNA is a component-based simulation tool, meaning that the model is formulated by connecting components together with nodes and adding operating conditions to create a system. The equations include mass and energy conservation for all components and nodes together with the relations for the thermodynamic properties of the fluids in the system. The total mass balance and energy balance for the entire system is also included to account for heat loss and heat exchange between different components. The program is written in FORTRAN, and users can implement additional components and thermodynamic state models to the libraries as well.

The main assumption within the calculations are

- No heat losses to the surroundings

- No resistance in the electrodes

- Constant utilization factor within all cells

- Constant current density for all cells

- Each cell is treated as a single point (eat and fluid flow is not calculated).

In reality, there exists some heat losses to the surrounding even though the stacks are well insulted. However, heat losses after insulation are very small and therefore negligible, although they can be accounted in the simulation. Resistance through the electrodes depends on the selection of material and one can select the material for the electrodes so that their resistance is very small and minor. Utilization may slightly varies from cell to cell, sometimes higher and sometimes lower, and therefore the assumption of constant utilization factor may be eligible. The same is true for the current density. The main limit of the modelling here is that the flow dynamic in the cells is not accounted, since the focus is on the plant level with all components. However, such technique is widely applicable/used for programs dealing with system level rather than component level.

\section{MODELLING}

\subsection{Modelling of SOFC}

The SOFC model proposed in a previous study [26],[27] is adopted in this investigation and has been validated with experimental data on planar SOFCs. In the development of such models, one must distinguish between electrochemical modelling (to obtain cell voltage and cell efficiency), calculation of cell and stack power (via number of stacks and their connections) and finally the species compositions at the cell outlet. Each of these is explained below in details.

\subsubsection{Electrochemical Modelling}

First, one needs to calculate the cell voltage of SOFC, which can theoretically be expressed by Nernst equation. However, in reality there exist losses, which decreases the theoretical cell 
voltage. These losses are mainly activation loss (cell voltage decreases as soon as current starts drawn from the cell), ohmic loss (cell voltage decreases when current is increased; linear dependency) and concentration loss (the current is so high that further increase in current causes drop in cell voltage significantly). These losses must be calculated in detail, which are expressed below. The SOFC model proposed in a previous study [26],[27] is adopted in this investigation. For electrochemical modelling, the operational voltage $\left(E_{\text {cell }}\right)$ is represented by equation 1.

$$
E_{\text {cell }}=E_{\text {Nernst }}-\Delta E_{\text {act }}-\Delta E_{\text {ohm }}-\Delta E_{\text {conc }}
$$

where $E_{\text {Nernst }}, \Delta E_{a c t}, \Delta E_{\text {ohm }}$, and $\Delta E_{\text {conc }}$ are the Nernst ideal reversible voltage, activation polarization, ohmic polarization, and concentration polarization, respectively. Assuming that only $\mathrm{H}_{2}$ is electrochemically converted the Nernst equation can be written as shown in equations 2 and 3.

$$
E_{\text {Nernst }}=\frac{-\Delta g_{\mathrm{f}}{ }^{0}}{n_{\mathrm{e}} F}+\frac{R T}{n_{\mathrm{e}} F} \ln \left(\frac{p_{\mathrm{H}_{2}, \text { tot }} \sqrt{p_{\mathrm{O}_{2}}}}{p_{\mathrm{H}_{2} \mathrm{O}}}\right)
$$

$$
p_{\mathrm{H} 2, \mathrm{tot}}=p_{\mathrm{H} 2}+p_{\mathrm{CO}}+4 p_{\mathrm{CH} 4}
$$

where $\Delta g_{f}^{0}$ is the Gibbs free energy (for $\mathrm{H}_{2}$ reaction) at standard temperature and pressure. The water-gas shift reaction is very fast and therefore the assumption that $\mathrm{H}_{2}$ is the only species to be electrochemically converted is justified [28], [29]. In the above equations, $p_{\mathrm{H} 2}$ and $p_{\mathrm{H} 2 \mathrm{O}}$ are the partial pressures for $\mathrm{H}_{2}$ and $\mathrm{H}_{2} \mathrm{O}$, respectively. It should be noted that the steam reforming and the associated water gas shift reactions are efficiently modelled in the calculations.

The activation polarization can be evaluated using the Butler-Volmer equation [30]. The activation polarization term is isolated from the other polarization terms, to determine the charge transfer coefficients and the exchange current density from the experiments by the curve fitting technique. The activation polarization is expressed by equation 4 .

$$
\Delta E_{a c t}=\frac{R T}{(0.001698 T-1.254) F} \sinh ^{-1}\left[\frac{i_{d}}{2\left(13.087 T-1.096 \times 10^{4}\right)}\right],
$$

where $R, T, F$, and $i_{d}$ are the universal gas constant, operating temperature, Faraday constant, and current density, respectively.

The ohmic polarization [31] depends on the electrical conductivity of the electrodes as well as the ionic conductivity of the electrolyte. This is also validated with experimental data for a cell with a specified anode thickness $\left(t_{a n}\right)$, electrolyte thickness $\left(t_{e l}\right)$, and cathode thickness $\left(t_{c a}\right)$. The ohmic polarization is given as follows.

$$
\Delta E_{o h m}=\left(\frac{t_{a n}}{\sigma_{a n}}+\frac{t_{e l}}{\sigma_{e l}}+\frac{t_{c a}}{\sigma_{c a}}\right) i_{d},
$$

where $t_{a n}=600 \mu \mathrm{m}, t_{e l}=50 \mu \mathrm{m}$, and $t_{c a}=10 \mu \mathrm{m}$. $\sigma_{a n}, \sigma_{e l}$, and $\sigma_{c a}$ are the conductivities of the anode, electrolyte, and cathode, respectively, and may be expressed as follows.

$$
\begin{aligned}
& \sigma_{a n}=10^{5}, \quad \sigma_{c a}=\frac{5.760 \times 10^{7}}{T} \exp \left(-\frac{0.117}{8.617 \times 10^{-5} T}\right) \\
& \sigma_{e l}=8.588 \times 10^{-8} T^{3}-1.101 \times 10^{-4} T^{2}+0.04679 T-6.54
\end{aligned}
$$


The concentration polarization is dominant at high current densities for anode-supported SOFCs, wherein insufficient amounts of reactants are transported to the electrodes and consequently, the voltage is reduced significantly. As in the previous case, the concentration polarization was validated with experimental data by introducing the anode limiting current, [32], in which the anode porosity and tortuosity were considered among other parameters. The concentration polarization is modelled as shown in equation 8 .

$$
\Delta E_{\text {conc }}=B\left(\ln \left(1+\frac{p_{\mathrm{H}_{2}} i_{d}}{p_{\mathrm{H} 2 \mathrm{O}} i_{a s}}\right)-\ln \left(1-\frac{i_{d}}{i_{a s}}\right)\right),
$$

where $B$ is the diffusion coefficient, which is determined using a calibration technique as

$$
\mathrm{B}=\left(0.008039 \mathrm{X}_{\mathrm{H} 2}^{-1}-0.007272\right) \frac{T}{T_{r e f}}
$$

$T_{r e f}$ is the reference temperature $(1023 \mathrm{~K})$, and the anode limiting current is defined as

$$
i_{a s}=\frac{2 F p_{H 2} D_{b i n} V_{a n}}{R T t_{a n} \tau_{a n}},
$$

where $V_{a n}$ and $\tau_{a n}$ are the porosity (30\%) and tortuosity $(2.5 \mu \mathrm{m})$ of the anode, respectively. The binary diffusion coefficient is given by

$$
D_{b i n}=\left(-4.107 \times 10^{-5} X_{H 2}+8.704 \times 10^{-5}\right)\left(\frac{T}{T_{r e f}}\right)^{1.75} \frac{p_{r e f}}{p},
$$

which is also calibrated against the experimental data. $p_{r e f}$ is the reference pressure $(1.013$ bar), and $X_{H 2}$ is the mass reaction rate of $\mathrm{H}_{2}$. Lastly, the current density $i_{d}$ is directly proportional to the amount of reacting $\mathrm{H}_{2}$ according to Faraday's law (equation 12).

$$
i_{d}=\frac{\dot{n}_{H 2} 2 F}{A},
$$

where $n_{H_{2}}$ is the molar reaction rate of $\mathrm{H}_{2}$. The area $\mathrm{A}$ is a physical property of the cell and was $144 \mathrm{~cm}^{2}$ in this study.

The SOFC model in this study aims at representing the performance of the second generation SOFC stacks developed by Topsoe Fuel Cell A/S (TOFC) and the Fuel Cells and Solid State Chemistry Division at Ris $\varnothing$ - DTU (Technical University of Denmark). This SOFC type is anode supported, with a Ni/YSZ 1 anode, a YSZ electrolyte, and an $\mathrm{LSM}^{2} / \mathrm{YSZ}$ cathode [33].

\subsubsection{Stack Power and Related Calculations}

Once the cell voltage is calculated then the stack power the power production from the SOFCs $\left(P_{S O F C}\right)$ can be decided using the equation (13). As shown, it depends on the amount of chemical energy fed to the anode, the reversible efficiency $\left(\eta_{r e v}\right)$, the voltage efficiency $\left(\eta_{v}\right)$, and the fuel utilization factor $\left(U_{F}\right)$. It is defined in the mathematical form as.

$$
P_{S O F C}=\left(\mathrm{LHV}_{\mathrm{H}_{2}} \dot{n}_{\mathrm{H}_{2}, \text { in }}+\mathrm{LHV}_{C O} \dot{n}_{C O, \text { in }}+\mathrm{LHV}_{\mathrm{CH}_{4}} \dot{n}_{\mathrm{CH}_{4}, \text { in }}\right) \eta_{\text {rev }} \eta_{v} U_{F}
$$

where $U_{F}$ is a constant and $\eta_{v}$ is defined as follows.

\footnotetext{
${ }^{1}$ Yttria-stabilized zirconia.

${ }^{2}$ Lanthanum strontium manganite.
} 


$$
\eta_{\mathrm{v}}=\frac{\Delta E_{\text {cell }}}{E_{\text {Nernst }}}
$$

Note that the utilization factor in SOFCs can be defined as the amount of $\mathrm{O}_{2}$ consumed, because $\mathrm{O}_{2}$ ions are the carriers. The reversible efficiency is the maximum possible efficiency, which is defined as the relationship between the maximum electrical energy available (change in Gibbs free energy) and the LHV (lower heating value) of the fuels, as shown below [34].

$$
\begin{aligned}
\eta_{\text {rev }}=\frac{\left(\Delta \bar{g}_{f}\right)_{\text {fuel }}}{\mathrm{LHV}_{\text {fuel }}} & \\
\left(\Delta \bar{g}_{f}\right)_{\text {fuel }} & =\left[\left(\bar{g}_{f}\right)_{\mathrm{H}_{2} \mathrm{O}}-\left(\bar{g}_{f}\right)_{\mathrm{H}_{2}}-\frac{1}{2}\left(\bar{g}_{f}\right)_{\mathrm{O}_{2}}\right] y_{\mathrm{H}_{2}, \text { in }} \\
& +\left[\left(\bar{g}_{f}\right)_{\mathrm{CO}_{2}}-\left(\bar{g}_{f}\right)_{\mathrm{CO}}-\frac{1}{2}\left(\bar{g}_{f}\right)_{\mathrm{O}_{2}}\right] y_{\mathrm{CO}, \text { in }} \\
& +\left[\left(\bar{g}_{f}\right)_{\mathrm{CO}_{2}}+2\left(\bar{g}_{f}\right)_{\mathrm{H}_{2} \mathrm{O}}-\left(\bar{g}_{f}\right)_{\mathrm{CH}_{4}}-2\left(\bar{g}_{f}\right)_{\mathrm{O}_{2}}\right] y_{\mathrm{CH}_{4}, \text { in }}
\end{aligned}
$$

where $\Delta \bar{g}$ is the average Gibbs free energy from the inlet to the outlet and $y$ is the mole fraction. The partial pressures are assumed to be the average pressures between the inlet and the outlet.

$$
\begin{aligned}
& \bar{p}_{j}=\left(\frac{y_{j, \text { out }}+y_{j, \text { in }}}{2}\right) \bar{p} \quad j=\left\{\mathrm{H}_{2}, \mathrm{CO}, \mathrm{CH}_{4}, \mathrm{CO}_{2}, \mathrm{H}_{2} \mathrm{O}, \mathrm{N}_{2}\right\} \\
& \bar{p}_{\mathrm{O}_{2}}=\left(\frac{y_{\mathrm{O}_{2}, \text { out }}+y_{\mathrm{O}_{2}, \text { in }}}{2}\right) \bar{p}_{\mathrm{c}}
\end{aligned}
$$

\subsubsection{Fuel Composition}

Finally, one needs to calculate the fuel composition at outlet of the cells. The compositions at outlets is calculated using the Gibbs minimization method [35]. First the unreacted fuels at outlet is decided by fuel cell utilization factor, then equilibrium at the anode outlet temperature and pressure is assumed for $\mathrm{H}_{2}, \mathrm{CO}, \mathrm{CO}_{2}, \mathrm{H}_{2} \mathrm{O}, \mathrm{CH}_{4}$, and $\mathrm{N}_{2}$. Finally, the Gibbs minimization method is used to calculate the compositions of these species at the outlet by minimizing their Gibbs energy. Gibbs minimization method facilities calculating of the composition without taking into account the chemical reaction paths. The reason is that all the chemical reactions tends to undergo in a way that the Gibbs energy will be minimum, as explained in [35]. Similar calculations can also be carried out for the cathode side.

\subsubsection{Validation}

A comparison between the SOFC model developed here and the experimental data is shown in Fig. 3, in terms of current density and cell voltage (IV curve). As seen from the figure, the model captures the experimental data very well at different fuel compositions with a standard error of less than 0.01 unless for $10 \% \mathrm{H}_{2}$ which was 0.05 . Different stack operating temperatures were used when developing the model. However, only the data for $750 \mathrm{C}$ is shown here. $97 \% \mathrm{H}_{2}$ with $3 \%$ water vapour is shown in Fig. 3. four different cell operating temperatures from $650{ }^{\circ} \mathrm{C}$ to $800{ }^{\circ} \mathrm{C}$

Figure 3. Cell voltage versus current density and a comparison between the modelling results and experimental data at $750^{\circ} \mathrm{C}$ with different fuel compositions.

\subsubsection{Additional Considerations}

Additionally, equations for conservation of mass (with molar flows), conservation of energy, and conservation of momentum were also included in the model. Table 1 displays the main 
parameters for the SOFC stacks used in this study. Operating temperature of the fuel cell is based on the experimental data presented in [33]. A temperature difference of $130{ }^{\circ} \mathrm{C}$ to $180{ }^{\circ} \mathrm{C}$ is applied to avoid thermal stresses in the cells, see e.g. [26]. The assumption of pressure drops is based on a simple calculation for heat exchangers via friction factor and Reynold number (see, e.g. [36]). Number of cells in one stack is assumed so that each stack generates about 1.2 $\mathrm{kW}$. The assumption of DC/AC convertor efficiency is somewhat low due to small size of the plant. Note that stack power is set to $10.2 \mathrm{~kW}$ which is achieved by varying fuel inlet mass flow. Thus plant can generate about $10 \mathrm{~kW}$ net powers after auxiliary power consumption. The sensitivity analysis of these values have already been widely discussed in previous publications, such as in [13], [26] and [37] and therefore there is no need to repeat them here.

Table 1. The main SOFC parameters used in this study [13], [8].

\subsection{Modelling of Methanator}

A simple Gibbs reactor, where the total Gibbs free energy is minimized upon reaching chemical equilibrium, is implemented to calculate the gas composition at a specified temperature and pressure without considering the reaction pathways [35]. The Gibbs free energy of a gas (which is assumed to be a mixture of $k$ perfect gases) can be written as

$$
\dot{G}=\sum_{i=1}^{k} \dot{n}_{i}\left[g_{i}^{0}+R T \ln \left(n_{i} p\right)\right]
$$

where $g^{0}, R$, and $T$ are the specific Gibbs free energy, universal gas constant, and gas temperature respectively. Each element in the inlet gas is in balance with the outlet gas composition, implying that the flow of each constituent has to be conserved. For $N$ elements, this balance is expressed by equation 19 .

$$
\sum_{i=1}^{k} \dot{n}_{i, i n} \mathbf{A}_{i j}=\sum_{m=1}^{w} \dot{n}_{m, o u t} \mathbf{A}_{m j} \quad \text { for } j=1, N
$$

The $N$ elements correspond to $\mathrm{H}_{2}, \mathrm{O}_{2}, \mathrm{~N}_{2}, \mathrm{CO}, \mathrm{NO}, \mathrm{CO}_{2}$, steam, $\mathrm{NH}_{3}, \mathrm{CH}_{4}, \mathrm{C}, \mathrm{NO}_{2}, \mathrm{HCN}$ (hydrogen cyanide) and $\mathrm{Ar}$, and in the methanation process. $\mathbf{A}_{\mathrm{mj}}$ is the number of atoms of element $\mathrm{j}(\mathrm{H}, \mathrm{C}, \mathrm{O}$, and $\mathrm{N})$ in each molecule of the entering compound $\mathrm{i}\left(\mathrm{H}_{2}, \mathrm{CH}_{4}, \mathrm{CO}, \mathrm{CO}_{2}\right.$, $\mathrm{H}_{2} \mathrm{O}, \mathrm{O}_{2}, \mathrm{~N}_{2}$, and $\mathrm{Ar}$ ), whereas $\mathbf{A}_{\mathrm{ij}}$ is the number of atoms of element $j$ in each molecule of the leaving compound $m\left(\mathrm{H}_{2}, \mathrm{O}_{2}, \mathrm{~N}_{2}, \mathrm{CO}, \mathrm{NO}, \mathrm{CO}_{2}\right.$, steam, $\mathrm{NH}_{3}, \mathrm{CH}_{4}, \mathrm{C}, \mathrm{NO}_{2}, \mathrm{HCN}$ and $\left.\mathrm{Ar}\right)$. The minimization of the Gibbs free energy can be mathematically formulated by introducing a Lagrange multiplier $(\mu)$ for each of the $N$ constraints. After adding the constraints, the expression to be minimized is given by

$$
\phi=\dot{G}_{\text {tot }, \text { out }}+\sum_{j=1}^{N} \mu_{j}\left(\sum_{i=1}^{k} \dot{n}_{i, o u t} A_{i j}-\sum_{m=1}^{w} \dot{n}_{m, i n} A_{m j}\right)
$$

By setting the partial derivative of this equation with respect to $\dot{n}_{i, o u t}$ to zero, the function $\phi$ can be minimized as 


$$
\begin{aligned}
& \frac{\partial \phi}{\partial \dot{n}_{i, \text { out }}}=\frac{\partial \dot{G}_{\text {tot }, \text { out }}}{\partial \dot{n}_{i, \text { out }}}+\sum_{j=1}^{N} \mu_{j} \mathbf{A}_{i j}=0 \quad \text { for } i=1, k \\
& \Rightarrow \quad g_{i, \text { out }}^{0}+R T \ln \left(n_{i, \text { out }} p_{\text {out }}\right)+\sum_{j=1}^{N} \mu_{j} \mathbf{A}_{i j}=0 \quad \text { for } i=1, k
\end{aligned}
$$

Thus, a set of $k$ equations are defined for each chemical compound leaving the system. Solving these equations gives the composition leaving the methanator.

\subsection{Modelling of Other Components}

The power consumption of the pumps was calculated as in equation 22 .

$$
W_{\text {pump }}=\left[\frac{\dot{m} v_{\text {in }}\left(p_{\text {out }}-p_{\text {in }}\right)}{\eta}\right]_{\text {pump }}
$$

where $\dot{m}, p, v$ and $\eta$ are the mass flow, pressure, specific volume $\left(\mathrm{m}^{3} / \mathrm{kg}\right)$ and efficiency of the pump, respectively. The pump efficiency is defined as shown below.

The power consumption of the compressors was modeled based on the definitions of isentropic and mechanical efficiencies (given values) in equations 23 and 24.

$$
\begin{aligned}
& \eta_{\text {is }}=\left[\frac{h_{\text {out }, \text { in }}-h_{\text {in }}}{h_{\text {out }}-h_{\text {in }}}\right]_{\text {compressor }} \\
& \eta_{m}=\left[\frac{\dot{m}\left(h_{\text {out }}-h_{\text {in }}\right)}{W}\right]_{\text {compressor }}
\end{aligned}
$$

where $h$ is the enthalpy. $h_{S}$ is the enthalpy when the entropy is constant. The subscripts in and out refer to the inlet and outlet of the component.

In modeling the heat exchanger, it was assumed that all energy from one side is transferred to the other side by neglecting the heat losses. Depending on the type of heat exchanger used, both the LMTD (logarithmic mean temperature difference) and $\varepsilon$-NTU (effectiveness-number of transferred unit) methods were used (see [36]).

Table 2. The main parameters for the accessory components [13], [26].

The desulfurizer unit is a simple model in which the sulfur content is removed. The compositions are re-calculated after sulfur removal. The main parameters for the accessory components are presented in Table 2. The pressure drops for all heat exchangers are assumed to be 0.001 bar at the fuel side and 0.005 bar at the air side. Because the system is designed for low-scale power, the fuel and air mass flows tend to be small, resulting in lower efficiencies of the turbomachines. Therefore, the compressor isentropic efficiency and mechanical efficiency are assumed to be 0.6 and 0.95 , respectively.

\section{RESULTS AND CONCLUSIONS}

Different alternative fuels will be used in this investigation and the results of plant design as well as anode recirculation (fuel recirculation) will be discussed for each fuel. Fuels under attention are ammonia, pure hydrogen, ethanol, methanol, DME and natural gas. Depending on the fuel the plant design will be altered as discussed below. If needed a methanator is 
included into the plant design to enhance plant performance. It shall be noted that the performance of a methanator is different from a pre-reformer and therefore the carbon decomposition will not be sever in as in the case with natural gas. As mentioned above, studies on anode off-fuel recycling on plant efficiency are very limited and which makes the basis of this study. Different types of fuels are used to investigate the effect of anode recycling on plant efficiency, which may provide an in-depth understanding of why anode recycle shall be used and how it effect on plant efficiency.

\subsection{Ammonia}

The first fuel to be studied is ammonia for which the plant design is shown in Fig. 4a. Air is preheated in a cathode preheater (CP) before entering the cathode side of the fuel cell. On the other side, fuel is preheated in an anode preheater (AP) prior to the anode side of the fuel cell. The plant efficiency and power are calculated to be about $51.0 \%$ and $10.2 \mathrm{~kW}$ respectively, with 8 stacks of 74 cells per stack and pressure drops defined above. The fuel after the anode contains mainly of $60 \%$ steam, $25 \% \mathrm{~N}_{2}$ and $15 \% \mathrm{H}_{2}$ (molar fraction). Some traces of $\mathrm{CO}, \mathrm{CO}_{2}$ and $\mathrm{NH}_{3}$ can also be found as, $8.84 \times 10^{-5}, 4.12 \times 10^{-4}$ and $1.26 \times 10^{-3}$ respectively. Since the fuel amount after the anode (off-fuel) is extremely low then having anode recycle will not be necessary at all in such system, see Fig. 4b. Any anode off-fuel recycling decreases pant performance as shown in Fig. $4 \mathrm{~b}$.

\section{Figure 4. a) SOFC plant design fed by ammonia and b) effect of recycle ratio.}

Decreasing SOFC utilization factor allows more fuel to be available in the off-fuel and therefore it might be of interest to investigate if it has any impact on plant performance. Fig. 5 shows that regardless of utilization factor, no anode recycling is necessarily.

Figure 5. Effect SOFC fuel utilization factor on plant efficiency, fed by ammonia.

\subsection{Pure Hydrogen}

The second fuel to be studied is hydrogen for which the plant design will be the same in Fig. 4. Plant power and efficiency are calculated as 10.0 and $45.5 \%$ respectively. The off-fuel after the anode-exit contains mainly of $20 \% \mathrm{H}_{2}$ and $80 \%$ steam (again molar basis). Traces of $\mathrm{CO}, \mathrm{CO}_{2}$ and $\mathrm{CH}_{4}$ can also be found which are very small to be discussed. Since the off-fuel contains of about $20 \%$ hydrogen then it would be necessarily to discuss an alternative plant design including anode recirculation as shown in Fig. 6. Fuel is preheated in a two steps heat exchangers; fuel preheater (FP) and anode preheater (AP) and in between these heat exchangers an ejector is placed (see. e.g. [38]). Note that inserting a pump instead of an ejector is very crucial due to high temperature of the off-fuel $\left(780{ }^{\circ} \mathrm{C}\right)$. A pump running on such high temperature must be costume made and thus extremely expensive.

\section{Figure 6. Plant design fed by hydrogen, alternative design.}

The recycling ratio of an ejector cannot be regulated and depends entire on the pressure difference between the ejector mail flow (fuel) and secondary flow (off-fuel to be recycled). Neglecting this issue the effect of off-fuel recirculation on plant efficiency is shown in Fig. 7a. As can be seen increasing recycling decreases plant efficiency (LHV) even though it can be found that there exist a certain amount of recycling for which the plant efficiency is maximum (about 12\% recycle). Below this value the efficiency does not change significantly. The reason is the interplay between fuel fraction (hydrogen molar fraction into the anode), 
Rokni M. Addressing Fuel Recycling in Solid Oxide Fuel Cell Systems Fed by Alternative Fuels. Energy 2017;137:1013-1025. DOI: 10.1016/j.energy.2017.03.082

fuel mass flow (to keep stack power constant at $10.2 \mathrm{~kW}$ ) and compressor excess power consumption (to keep stack temperature at $780{ }^{\circ} \mathrm{C}$ in addition to the oxygen needed).

\section{Figure 7. Effect of recycling on a SOFC plant fed by hydrogen, a) $U_{f}=0.8$ and $\left.b\right) U_{f}=0.7$.}

Decreasing the fuel utilization changes the picture completely as demonstrated in Fig. 7b. For the case of $U_{f}=0.7$, plant efficiency increases by increasing anode recycle. The reason is that more fuel will be available in the anode off-fuel when utilization factor is decreased resulting in favour for plant efficiency by recycling. Thus the general conclusion is that at high utilization factors (more than about 0.8 ) increasing anode recycle decreases plant efficiency while at low utilization factors (less than about 0.8) increasing SOFC fuel utilization will in favour for plant efficiency. This is also revealed in Fig. 8.

For example plant efficiency increases significantly sharper for the case with 0.6 utilization factor when anode recycle is applied, while the increase in plant efficiency is less pronounced for the case with 0.7 utilization factor with increasing anode recycle. Foe the case with $U_{f}=0.7$ the anode recycle needs to be about $40 \%$ to reach same efficiency as the case with $U_{f}=0.8$ and $20 \%$ off-fuel recycle. The anode recycle must be much more than $50 \%$ for the case with $U_{f}=0.6$ to reach the same efficiency as in the case with $U_{f}=0.8$ and $20 \%$ off-fuel recycle.

\section{Figure 8. Effect SOFC fuel utilization factor on plant efficiency, fed by hydrogen.}

An alternative plant design for pure hydrogen may be designed as shown in Fig. 4a, in which fuel preheater is removed and instead the anode preheater may also work as fuel preheater. Thus, plant design is similar as in the case with pure ammonia. The duty of the anode preheater (or fuel preheater) is increased and some saving in investment cost can be achieved. The disadvantage of such design is that pressure drop along the off-fuel will be higher than the previous case and therefore less pressure drop for the ejector between main flow and secondary flow, which in turn makes the ejector not be able to recycle the off-fuel as efficient as the previous case. On the other hand, in such design, the temperature of the fuel entering the anode side of the fuel cell increases with increasing recycle ratio and at some point fuel temperature will reach to the limit and therefore additional recycling will not be feasible.

Plant performance of such design is presented in Fig. 9. As shown, similar conclusion as the original design can also be drawn here. Plant performance increases with increasing recycle ratio at low utilization factors while at high utilization factor (e.g. $U_{f}=0.8$ ) this is not true. In fact, at $U_{f}=0.8$ plant performance remains almost constant although a maxima can be found which is around $12 \%$ recirculation.

\section{Figure 9. Effect of anode recycle for alternative plant design for hydrogen.}

\subsection{Methanol, Ethanol and DME}

The next fuels to be considered are methanol, ethanol and DME for which the plant design will be the same in Fig. 10. A methanator is included to reform the fuel into methane, hydrogen and carbon monoxide which in turn are considered to be fuel for solid oxide fuels. Then an ejector is placed prior to the methanator to mix the fuel with off-fuel out of the anode side of the fuel cell. Two plant configurations are considered here; one with anode preheater and one without anode preheater. In the case of anode preheater the fuel is preheated to a lower temperature such as $280{ }^{\circ} \mathrm{C}$ which is well above the minimum temperature $\left(250{ }^{\circ} \mathrm{C}\right)$ for complete reforming of the fuel in the presence of a catalyst (see e.g. [11]). In fact any values between $250{ }^{\circ} \mathrm{C}$ and $400{ }^{\circ} \mathrm{C}$ can be used without altering the plant performances. Due to 
Rokni M. Addressing Fuel Recycling in Solid Oxide Fuel Cell Systems Fed by Alternative Fuels. Energy 2017;137:1013-1025. DOI: 10.1016/j.energy.2017.03.082

endothermic nature of the reforming process the outlet temperature of the methanator will be much higher than its inlet.

\section{Figure 10. Plant design fed by methanol, ethanol and DME.}

The reforming process within the methanator need steam which is available after the anode side of the fuel cell, the so called off-fuel. Plant performance depends on how much off-fuel can be recycled through the ejector, which in turn depends on the pressure difference from the main flow to the secondary flow (injection). Both steam and unreacted fuel in the off-fuel can thus be recycled back into the anode side of the fuel cell, see Fig. 10.

As mentioned above, steam is needed for operating the methanator and therefore some offfuel shall be recycled. With respect to the plant efficiency, recycling $20 \%$ of the anode off-fuel would be suitable when $U_{f}=0.8$. With $20 \%$ anode recycling then enough steam is available in the fuel for fuel decomposition and water gas shift reaction (in the presence of a catalyst such as copper supported on zinc oxide) which are the essential reactions associated with a methanator. Increasing the recycling ratio decreases plant efficiency and the reason is that for such high utilization factor the amount of steam is much more than the fuel in the off-fuel. Therefore, by increasing the recycling ratio more steam will be recycled which would have negative impact on the plant performance. Cell voltage decreases and current density increases to keep the output power at $10.2 \mathrm{~kW}$, see Fig. 11a through Fig. 13a.

However, for the case with lower utilization factor (for example $U_{f}=0.7$ ) then the situation is changed. Increasing anode recycle increases plant efficiency to a certain point as shown in Fig. $11 \mathrm{~b}$ though $13 \mathrm{~b}$. The reason is that now more fuel will be available in the off-fuel, which would be in favour of cell performance up to a certain amount. Further increase in recycling ratio changes the ratio between the fuel and steam in the off-fuel and therefore it will decrease cell performance. Plant efficiency is maximized when anode recycle is about $43 \%, 41 \%$ and $43 \%$ for ethanol, methanol and DME, respectively.

As demonstrated, at high utilization factors (about 0.8 ) anode recycle should be kept as low as possible so that the amount of steam is enough for the methanator while at low utilization factors higher anode recycle is recommended.

\section{Figure 11. Effect of recycling on a SOFC plant fed by ethanol, a) $U_{f}=0.8$ and $\left.b\right) U_{f}=0.7$.}

Figure 12. Effect of recycling on a SOFC plant fed by methanol, a) $U_{f}=0.8$ and $\left.b\right) U_{f}=0.7$.

$$
\text { Figure 13. Effect of recycling on a SOFC plant fed by DME, a) } \left.U_{f}=0.8 \text { and } b\right) U_{f}=0.7 \text {. }
$$

Again, similar conclusion as in the case with pure hydrogen can be drawn here, low anode recirculation for high utilization factors (about 0.8) and high anode recycle for low utilization factors, see also Fig. 14 for better comparison. Note that anode recycle is essential for fuels with methanator, which is due to available steam in the off-fuel required for methanation process. Thus, approximately $20 \%$ of anode recycle for high utilization factors (such as $80 \%$ ) and about $40 \%$ anode recycle for low utilization factors (about 70\%). Further decrease in utilization, requires higher anode recycling to compensate plant efficiency drop caused by low utilization factors.

As it is displayed in Fig.14a, for the case with $U_{f}=0.8$, plant efficiency (LHV) decreases as anode recycle is increased, this is more distinct when anode off-fuel recycling is more than about $25 \%$. Lowering utilization factor to 0.7 , then there is exist an optimum for which plant efficiency maximizes, see Fig. $14 \mathrm{~b}$. 
Rokni M. Addressing Fuel Recycling in Solid Oxide Fuel Cell Systems Fed by Alternative Fuels. Energy 2017;137:1013-1025. DOI: 10.1016/j.energy.2017.03.082

\section{Figure 14. Effect of recycling on a SOFC plant fed by methanol, ethanol and DME, a) $U_{f}=0.8$} and $b) U_{f}=0.7$

\subsection{Biogas}

Biogas investigated in this study has its origin from the biomass gasification considered in [37]. The composition of the biogas (syngas) is assumed to be

$$
\begin{aligned}
& \mathrm{H}_{2}=0.2532, \\
& \mathrm{~N}_{2}=0.2877, \\
& \mathrm{CO}=0.1718, \\
& \mathrm{CO}_{2}=0.1159, \\
& \mathrm{H}_{2} \mathrm{O} \text { (steam) }=0.1578, \\
& \mathrm{CH}_{4}=0.0102 \text { and } \\
& \mathrm{Ar}=0.0034,
\end{aligned}
$$

which is based on the study of [37]. Since the quality of the fuel is substantially lower compared to the other fuels, the number of stacks is increased to 20 to compensate the plant performance, which otherwise this case cannot be studied throughout and in line with other fuels. Plant design is the same as the case for methanol, ethanol and DME, meaning that the fuel side includes a fuel preheater (FP), methanator and anode preheater (AP) while the cathode side includes a cathode preheater $(\mathrm{CP})$ prior to the stack. Both off-fuel and off-air are send to a burner to combust the remaining fuel. Again, the recycle device is placed as far away as from the fuel to allow more pressure drop, which facilitates the use of an ejector.

As revealed in Fig. 15a, increasing off-fuel recycling decreases stack voltage and therefore current density must be increased to reach the imposed stack power at $10.2 \mathrm{~kW}$. At such high utilization factor $\left(U_{f}=0.8\right)$ the off-fuel after the anode side of the stack contains mostly of water and recycling the off-fuel results in mostly water recirculation which has a negative impact on the cell voltage. Decreasing utilization factor to $U_{f}=0.6$, results in higher amount of fuel available in the off-fuel after the anode side and therefore anode fuel recirculation will be in favour and plant efficiency increases as a consequent, (see Fig. 15c). When utilization factor is $0.7\left(U_{f}=0.7\right)$, then plant performance does not change significantly (because of composition of the fuel after mixing) and therefore off-fuel recycling would not be necessary (see Fig. 15b).

Figure 15. Effect of recycling on a SOFC plant fed by biogas from biomass gasification, a) $U_{f}=$ $0.8, b) U_{f}=0.7$ and $\left.c\right) U_{f}=0.6$.

Again, at high utilization factor fuel recycling is not necessarily while at low utilization it is recommended, which is also demonstrated in Fig. 16. For the case with $U_{f}=0.8$ plant efficiency decreases sharply from $36.2 \%$ to $29.4 \%$ when anode off-fuel recycling is increased from 0 to $20 \%$.

\section{Figure 16. Effect of recycling on a SOFC plant fed by biogas from biomass gasification, a) $U_{f}=$} 0.8 and $b) U_{f}=0.6$.

If utilization factor is decreased to 0.7 , then there would be more fuel available in the off-fuel and therefore plant efficiency increases slightly when anode recycling is increased. Such increase is small, from $37.4 \%$ to $37.9 \%$ when anode recycling reaches to $20 \%$. Further decrease in utilization factor results in sharper increase in plant performance. For the case with $U_{f}=0.6$, plant efficiency increases from $34.3 \%$ to $36.1 \%$, as off-fuel recycling is increases from 0 to $20 \%$.

As mentioned above, the number of stacks was increased to compensate fuel quality of the biogas and have a throughout comparison with other fuels. However, it is also possible to decrease the number of stacks to 8 as it was the case for the other fuels mentioned above. 
Consequently, plant performance will decrease from about $36 \%$ to about $33 \%$ if fuel cell utilization factor is decreased significantly (not more than about 0.6), as seen in Fig. 17. Here again, at high utilization factor (comparably when $U_{f}=0.7$ ), then there is no need for off-fuel recirculation while at lower utilization factors there exist a point for which plant efficiency is maximizes. The optimum recirculation is $65 \%, 45 \%$ and $20 \%$ when utilization factor is $0.4,0.5$ and 0.6 respectively. Note also that when $U_{f}=0.7$ then plant performance decreases suddenly with any fuel recirculation; see the line in the bottom left corner.

Another important point is that the optimum recirculation increases when utilization factor decreases, allowing more off-fuel to be recycled to compensate fuel utilization in the stacks. The sudden decrease in plant performance after the optimum point is that the mixed fuel and off-fuel consists of too much amount of nitrogen and steam (more than 50\%), which have negative effect on stack voltage. It should also be mentioned that practically an ejector cannot recycle more than $50 \%$ of its incoming fuel (main flow).

\section{Figure 17. Effect of recycling on a SOFC plant fed by biogas from biomass gasification when number of stacks is 8 .}

\section{CONCLUSION}

A new study on anode recirculation in SOFC plants with alternative fuels is presented. Fuels under study are ammonia, pure hydrogen, methanol, ethanol, DME and biogas from biomass. Some of the founding are;

- No anode recycling is needed when the plant is fed by ammonia.

- When the system is fed by pure hydrogen and utilization factor is $80 \%$, then the anode recirculation should be about $20 \%$. Further, plant fed by pure hydrogen has the lowest plant efficiency, which is due to endothermic nature of reactions inside the cells and therefore excessive air is needed to cool down the stacks and keep their temperature at the desired level.

- Anode recycle has a significant effect on plant efficiency when the SOFC plant is fed by hydrogen, ethanol, methanol and DME. At low SOFC fuel utilization factors, it is desirable to increase anode recycle to compensate for low utilization factors. However, at high SOFC fuel utilization factors less anode recycle is needed which otherwise decreases plant efficiency with increasing anode recycle.

- If the plant is fed by biogas from biomass then for each utilization factor, there exist an optimum anode recirculation, which maximizes plant efficiency. For example, the optimum recirculation is $65 \%, 45 \%$ and $20 \%$ when utilization factor is $0.4,0.5$ and 0.6 respectively.

- Plant efficiency of about $45 \%$ can be achieved if it is fed by pure hydrogen.

- Fed by Methanol and DME, the plant efficiency is about $51 \%$.

- Plant fed by Ethanol has the highest efficiency, which is about 55\%.

- Due to low quality fuel of biogas, plant efficiency will not be more than about $33 \%$.

In addition, plant designs for different fuels than natural gas is presented/analysed such as ammonia, pure hydrogen, methanol, ethanol and DME and biogass. The simplest plant design is associated with ammonia while in the plants fed by ethanol, methanol, DME and biogas (from biomass) a methanator is included to enhance plant performance.

\section{REFERENCES}

1. Calise F, Dentice d'Accadia M, Palombo A, Vanoli L. Simulation and exergy analysis of a hybrid solid oxide fuel cell (SOFC)-Gas turbine system. Energy 2006;31:3278-99. 
Rokni M. Addressing Fuel Recycling in Solid Oxide Fuel Cell Systems Fed by Alternative Fuels. Energy 2017;137:1013-1025. DOI: 10.1016/j.energy.2017.03.082

654

655

656

657

658

659

660

661

662

663

664

665

666

667

668

2. Rokni M, Introduction of a fuel cell into combined cycle: a competitive choice for future cogeneration, ASME Cogen - Turbo IGTI 1993; 8: 255-261.

3. Komatsu Y, Kimijima S and Szmyd JS. Performance analysis for the part-load operation of a solid oxide fuel cell-micro gas turbine hybrid system. Energy 2010; 35: 982-988.

4. Jia J, Abudula A, Wei L, Sun B, Shi Y. Thermodynamic modeling of an integrated biomass gasification and solid oxide fuel cell system. Renewable Energy 2015;81:400-410.

5. Farhad S, Hamdullahpur F, Yoo Y. Performance evaluation of different configurations of biogas-fuelled SOFC micro-CHP systems for residential applications. Hydrogen Energy 2010;35:3758-3768.

6. Papurello D, Lanzini A, Tognana L, Silvestri S, Santarelli M. Waste to energy: Exploitation of biogas from organic waste in a $500 \mathrm{~W}_{\mathrm{el}}$ solid oxide fuel cell (SOFC) stack. Energy 2015;85:145-158.

7. Gandiglio M, Lanzini A, Santarelli M, Leone P. Design and balance-of-plant of a demonstration plant with a solid oxide fuel cell fed by biogas from waste-water and exhaust carbon recycling for algae growth. Fuel Cell Science and Technology 2014;11:31003.

8. Bellomare F, Rokni M. Integration of a municipal solid waste gasification plant with solid oxide fuel cell and gas turbine. Renewable Energy 2013;55:490-500.

9. Leone P, Lanzini A, Ortigoza-Villalba GA and Borchiellini R. Operation of a solid oxide fuel cell under direct internal reforming of liquid fuels. Chemical Engineering 2012;191:349-355.

10.Cocco D and Tola V. Externally reformed solid oxide fuel cell-micro-gas turbine (SOFCMGT) hybrid systems fueled by methanol and di-methyl-ether (DME). Energy 2009;34: 2124-2130.

11.Jamsak W, Assabumrungrat S, Douglas PL, Croiset E, Laosiripojana N, Suwanwarangkul R and Charojrochkul S. Performance. Assessment of Bioethanol-Fed Solid Oxide Fuel Cell System Integrated with Distillation Column. ECS Transactions 2007; 7(1): 1475-1482.

12.Baniasadi E and Dincer I. Energy and exergy analyses of a combined ammonia-fed solid oxide fuel cell system for vehicular applications. Hydrogen Energy 2011; 36: 11128-11136.

13.Rokni M. Thermodynamic analysis of SOFC (solid oxide fuel cell) - Stirling hybrid plants using alternative fuels. Energy 2013;61:87-97.

14.Kihlman J, Sucipto J, Kaisalo N, Simell P, Lehtonen J. Carbon formation in catalytic steam reforming of natural gas with SOFC anode off-gas. Hydrogen Energy 2015;40:1548-1558.

15.Shekhawat D, Berry DA, Gardner TH, Haynes DJ, Spivey JJ. Effects of fuel cell anode recycle on catalytic fuel reforming. Power Sources 2007;168:477-483.

16.Eveloy V. Anode fuel and steam recycling for internal methane reforming SOFCs: analysis of carbon deposition. Fuel Cell Science and Technology 2011;8: 0110061-0110068.

17.Watanabe K, Yokoo M, Hayashi K, Arai H. Demonstration of principle of electrical power generation at high fuel utilization efficiency by an SOFC system with an anode recycle line. ECS Transactions 2011;30 (1):151-155.

18.Tanaka Y, Momma A, Sato K, Kato T. Improvement of electrical efficiency of solid oxide fuel cells by anode gas recycle. ECS Transactions 2011;30 (1):145-150.

19.Noponen M, Halinen M, Saarinen J, Kiviaho J. Experimental Study of Anode Gas Recycling on Efficiency of SOFC. ECS Transactions 2007;5(1):545-551.

20. Braun RJ, Klein SA, Reindl DT. Evaluation of system configurations for solid oxide fuel cell-based micro-combined heat and power generators in residential applications. Power Sources 2006;158:1290-1305.

21. Schluckner C, Subotic V, Lawlor V, Hochenauer C. Carbon Deposition Simulation in Porous SOFC Anodes: A Detailed Numerical Analysis of Major Carbon Precursors, ASME Fuel Cell Science and Technology 2015;12:051007:1-12.

22. Girona K, Laurencin J, Fouletier J, F. Lefebvre-Joud F. Carbon deposition in $\mathrm{CH}_{4} / \mathrm{CO}_{2}$ operated SOFC: Simulation and experimentation studies. Power Sources 2012;210:381-391. 
Rokni M. Addressing Fuel Recycling in Solid Oxide Fuel Cell Systems Fed by Alternative Fuels. Energy 2017;137:1013-1025. DOI: 10.1016/j.energy.2017.03.082

23. Yashiro K, Takase M, Sato K, Kawada T. Carbon deposition and electrochemical reaction of anode for SOFC in methane containing atmosphere. ECS Transactions 2009;16(51):213-218.

24.Hofmann PH, Schweiger A, Fryda L, Panopoulos KD, Hohenwarter U, Bentzen JD, Ouweltjes JP, Ahrenfeldt J, Henriksen U, Kakaras E High temperature electrolyte supported $\mathrm{Ni}-$ GDC/YSZ/LSM SOFC operation on two-stage Viking gasifier product gas. Power Sources 2007; 173:357-366.

25. Elmegaard B, Houbak N. DNA-a general energy system simulation tool. Proceeding of SIMS, Trondheim, Norway; 2005.

26. Rokni M. Thermodynamic investigation of an integrated gasification plant with solid oxide fuel cell and steam cycles. Green 2012;2:71-86.

27.Rokni M. Thermodynamic analyses of municipal solid waste gasification plant integrated with solid oxide fuel cell and Stirling hybrid system. Hydrogen Energy 2015;40:7855-7869.

28.Holtappels P, DeHaart LGJ, Stimming U, Vinke IC, Mogensen M. Reaction of CO/CO2 gas mixtures on Ni-YSZ cermet electrode. Applied Electrochemistry 1999;29:561-68.

29.Matsuzaki Y Yasuda I. Electrochemical oxidation of $\mathrm{H} 2$ and $\mathrm{CO}$ in a $\mathrm{H} 2-\mathrm{H} 2 \mathrm{O}-\mathrm{CO}-\mathrm{CO} 2$ system at the interface of a Ni-YSZ cermet electrode and YSZ electrolyte. Electrochemical Society 2000;147(5):1630-35.

30.Keegan KM, Khaleel M, Chick LA, Recknagle K, Simner SP, Diebler J. Analysis of a planar solid oxide fuel cell based automotive auxiliary power unit. SAE Technical Paper Series 2002;No. 2002-01-0413.

31.Zhu H, Kee RJ. A general mathematical model for analyzing the performance of fuel-cell membrane-electrode assemblies. Power Sources 2003;117:61-74.

32.Costamagna P, Selimovic A, Del Borghi M, Agnew G. Electrochemical model of the integrated planar solid oxide fuel cell (IP-SOFC). Chemical Engineering 2004;102(1):61-69.

33. Christiansen N, Hansen JB, Holm-Larsen H, Linderoth S, Larsen PH, Hendriksen PV, Hagen A. Solid oxide fuel cell development at Topsoe fuel cell and Risø. Electrochemical Society 2007;7(1):31-38.

34.Winnick J. 1997. Chemical engineering thermodynamics. John Wiley \&Sons, New Yourk.

35.Smith JM, Van Ness HC, Abbott MM. Introduction to Chemical Engineering Thermodynamics, 7th edition, Boston: McGraw-Hill, 2005.

36.Incropera FP, DeWitt DP, Bergman TL and Lavine AS. Introduction to Heat Transfer, $5^{\text {th }}$ edition, Wiley 2006, ISBN 978-0471457275.

37.Rokni, M. Biomass Gasification Integrated with a Solid Oxide Fuel Cell and Stirling Engine. Energy 2014;77:6-18.

38.Baba S, Kobayashi N, Takahashi S. Development of anode gas recycle system using ejector for $1 \mathrm{~kW}$ solid oxide fuel cell. Engineering for Gas Turbines and Power 2015;137:021504-1.

\section{Nomenclature}

A Area, $\mathrm{m}^{2}$

$\mathbf{A}_{i, j} \quad$ Matrix

B Diffusion coefficient

$D_{b i n} \quad$ Binary diffusion coefficient

$D_{\text {cell }} \quad$ Cell diameter, $\mathrm{m}$

$\dot{E} \quad$ Exergy flow rate, $\mathrm{kW}$

$E_{F C} \quad$ Electricity from fuel cell, $\mathrm{V}$

$E_{\text {Nernst }}$ Nernst ideal reversible voltage, $\mathrm{V}$

$F \quad$ Faradays constant, $\mathrm{C} / \mathrm{mol}$

$g^{0} \quad$ Standard Gibbs free energy, $\mathrm{J} / \mathrm{mol}$ 
$g_{f} \quad$ Gibbs free energy, $\mathrm{J} / \mathrm{mol}$

$h \quad$ Enthalpy, $\mathrm{J} / \mathrm{kg}$

$h_{f} \quad$ Enthalpy of formation, $\mathrm{J} / \mathrm{mol}$

$I_{\text {comp }} \quad$ Purchase cost of component $k$

Anode limiting current, $\mathrm{mA} / \mathrm{cm}^{2}$

$i_{d} \quad$ Current density, $\mathrm{mA} / \mathrm{cm}^{2}$

$L_{\text {cell }} \quad$ Cell length, $\mathrm{m}$

Molar reaction rate of $\mathrm{H}_{2}, \mathrm{~mol} / \mathrm{s}$

$732 \quad P \quad$ Power, W

$733 p \quad$ Pressure, bar

$734 p_{H 2}$ Partial pressure for $\mathrm{H}_{2}$, bar

$735 p_{\mathrm{H} 2 \mathrm{O}}$ Partial pressure for $\mathrm{H}_{2} \mathrm{O}$, bar

$736 \quad Q \quad$ Heat, $\mathrm{J} / \mathrm{s}$

$737 \quad T \quad$ Operating temperature, $\mathrm{K}$

$738 t \quad$ Thickness, $m$

$739 R \quad$ Universal gas constant, $\mathrm{J} / \mathrm{mol} \mathrm{K}$

$740 \quad U_{F} \quad$ Fuel utilization factor

$741 \quad V \quad$ Volume, $\mathrm{m}^{3}$

$742 \quad V_{a n} \quad$ Anode porosity

743 W Work, W

$744 \quad X_{H 2} \quad$ Mass reaction rate of $\mathrm{H}_{2}$

$745 \quad Y \quad$ Molar fraction

Greek symbols

$748 \Delta E_{a c t}$ Activation polarization, $\mathrm{V}$

$749 \Delta E_{\text {conc }}$ Concentration polarization, $\mathrm{V}$

$750 \Delta E_{\text {offset }}$ Offset polarization, $\mathrm{V}$

$751 \Delta E_{\text {ohm }}$ Ohmic polarization, $\mathrm{V}$

$752 \Delta T_{m l}$ Logarithmic mean temperature difference, $\mathrm{K}$

$753 \varepsilon \quad$ Effectiveness

$754 \quad \eta_{\text {rev }} \quad$ Reversible efficiency

$755 \quad \eta_{v} \quad$ Voltage efficiency

$756 \quad \eta_{\text {mec }}$ Mechanical efficiency

$757 \quad \eta_{\text {pump }}$ Efficiency of pump

$758 \quad \sigma \quad$ Conductivity, $\mathrm{S} / \mathrm{cm}$

$759 \tau_{a n} \quad$ Anode tortuosity, $\mathrm{m}$

$760 \quad v \quad$ specific volume, $\mathrm{m}^{3} / \mathrm{kg}$

Subscript

an Anode

ca Cathode

el Electrolyte

ref Reference

Abbreviations

AP Anode pre-heater

CP Cathode air pre-heater

DME Di-Methyl Ether

DNA Dynamic network analysis 
Rokni M. Addressing Fuel Recycling in Solid Oxide Fuel Cell Systems Fed by Alternative Fuels. Energy 2017;137:1013-1025. DOI: 10.1016/j.energy.2017.03.082

773 FP Fuel Preheater

774 LHV Lower heating value

775 NG Natural Gas

776 O/C Oxygen-Carbon ratio

777 S/C Steam-Carbon ratio

778 SOFC Solid oxide fuel cell

779

780 
Rokni M. Addressing Fuel Recycling in Solid Oxide Fuel Cell Systems Fed by Alternative Fuels. Energy 2017;137:1013-1025. DOI: 10.1016/j.energy.2017.03.082

\section{List of Figure Captions}

Figure 1. General fuel cell plant with anode off-fuel recirculation. CP: Cathode Preheater, AP: Anode Preheater.

Figure 2. Calculation procedure.

Figure 3. Cell voltage versus current density and a comparison between the modelling results and experimental data at $750^{\circ} \mathrm{C}$ with different fuel compositions.

Figure 4. a) SOFC plant design fed by ammonia and b) effect of recycle ratio.

Figure 5. Effect SOFC fuel utilization factor on plant efficiency, fed by ammonia.

Figure 6. Plant design fed by hydrogen, alternative design.

Figure 7. Effect of recycling on a SOFC plant fed by hydrogen, a) $U_{f}=0.8$ and b) $U_{f}=0.7$.

Figure 8. Effect SOFC fuel utilization factor on plant efficiency, fed by hydrogen.

Figure 9. Effect of anode recycle for alternative plant design for hydrogen.

Figure 10. Plant design fed by methanol, ethanol and DME.

Figure 11. Effect of recycling on a SOFC plant fed by ethanol, a) $U_{f}=0.8$ and b) $U_{f}=0.7$.

Figure 12. Effect of recycling on a SOFC plant fed by methanol, a) $U_{f}=0.8$ and b) $U_{f}=0.7$.

Figure 13. Effect of recycling on a SOFC plant fed by DME, a) $U_{f}=0.8$ and b) $U_{f}=0.7$.

Figure 14. Effect of recycling on a SOFC plant fed by methanol, ethanol and DME, a) $U_{f}=0.8$ and b) $U_{f}=0.7$

Figure 15. Effect of recycling on a SOFC plant fed by biogas from biomass gasification, a) $U_{f}=$ 0.8, b) $U_{f}=0.7$ and c) $U_{f}=0.6$.

Figure 16. Effect of recycling on a SOFC plant fed by biogas from biomass gasification, a) $U_{f}=$ 0.8 and b) $U_{f}=0.6$.

Figure 17. Effect of recycling on a SOFC plant fed by biogas from biomass gasification when number of stacks is 8 . 
Rokni M. Addressing Fuel Recycling in Solid Oxide Fuel Cell Systems Fed by Alternative Fuels. Energy 2017;137:1013-1025. DOI: 10.1016/j.energy.2017.03.082

Table Captions

809

810 Table 1. The main SOFC parameters used in this study [13], [8].

811 Table 2. The main parameters for the accessory components [13], [26].

812

813 
Rokni M. Addressing Fuel Recycling in Solid Oxide Fuel Cell Systems Fed by Alternative Fuels. Energy 2017;137:1013-1025. DOI: 10.1016/j.energy.2017.03.082

814

815

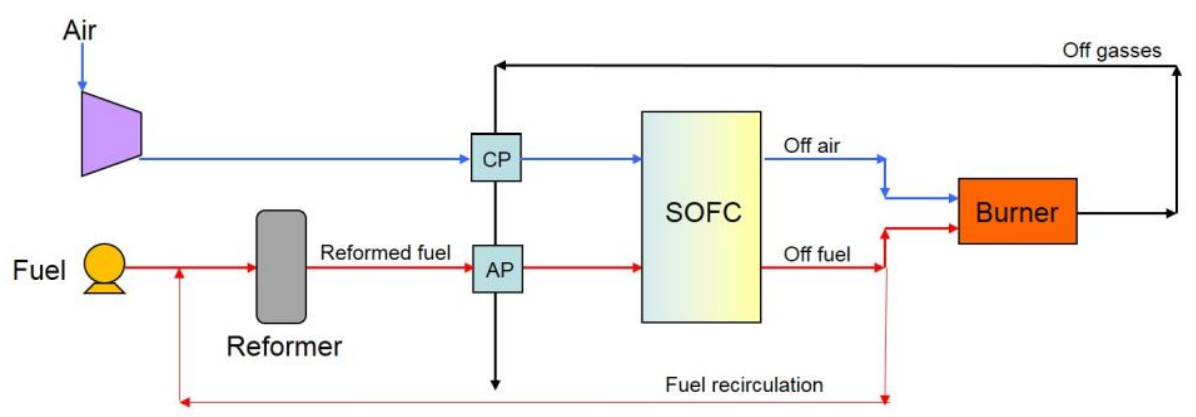

Figure 1. General fuel cell plant with anode off-fuel recirculation. CP: Cathode Preheater, AP: Anode Preheater. 
Rokni M. Addressing Fuel Recycling in Solid Oxide Fuel Cell Systems Fed by Alternative Fuels. Energy 2017;137:1013-1025. DOI: 10.1016/j.energy.2017.03.082

Figure 2. Calculation procedure.

833

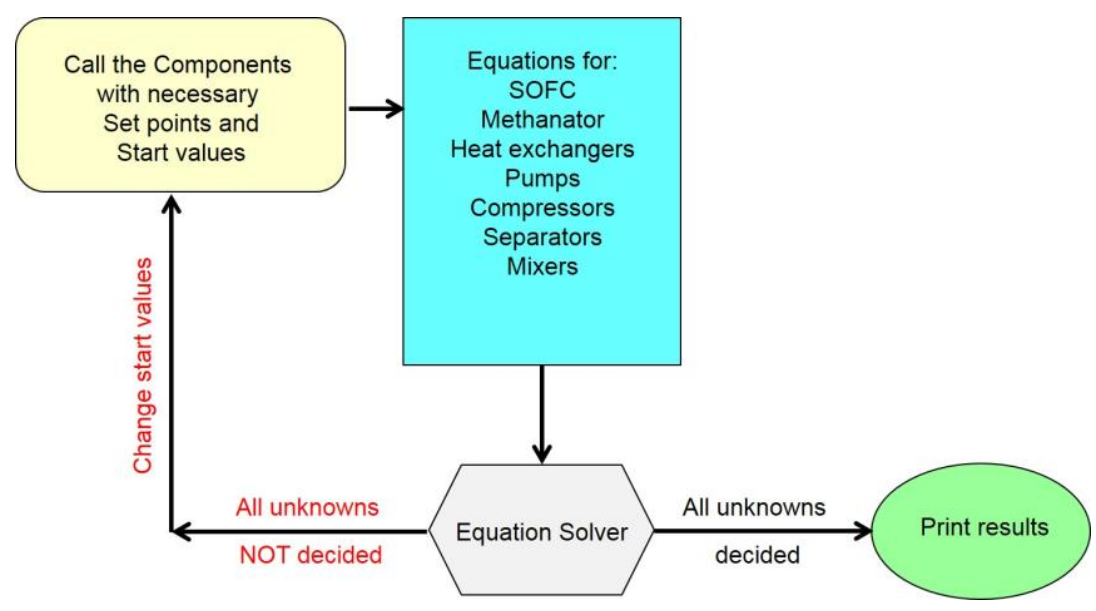

834 
Rokni M. Addressing Fuel Recycling in Solid Oxide Fuel Cell Systems Fed by Alternative Fuels. Energy 2017;137:1013-1025. DOI: 10.1016/j.energy.2017.03.082

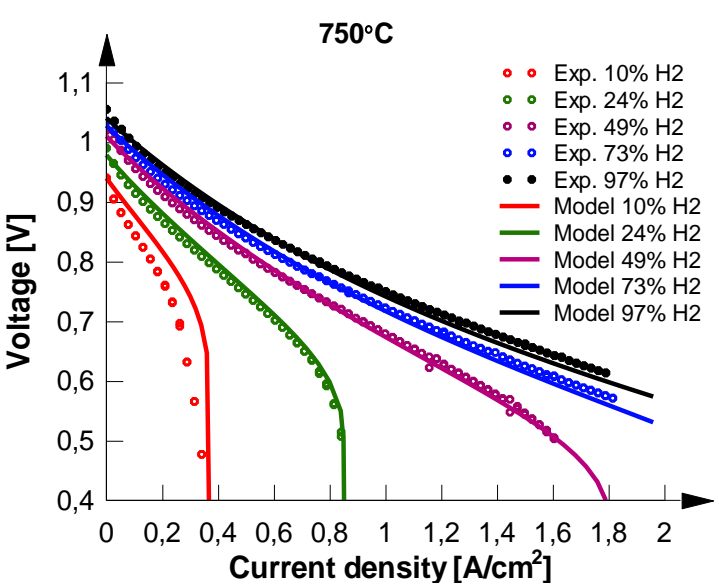

Figure 3. Cell voltage versus current density and a comparison between the modelling results 843 and experimental data at $750^{\circ} \mathrm{C}$ with different fuel compositions.

844

845 
Rokni M. Addressing Fuel Recycling in Solid Oxide Fuel Cell Systems Fed by Alternative Fuels. Energy 2017;137:1013-1025. DOI: 10.1016/j.energy.2017.03.082

846
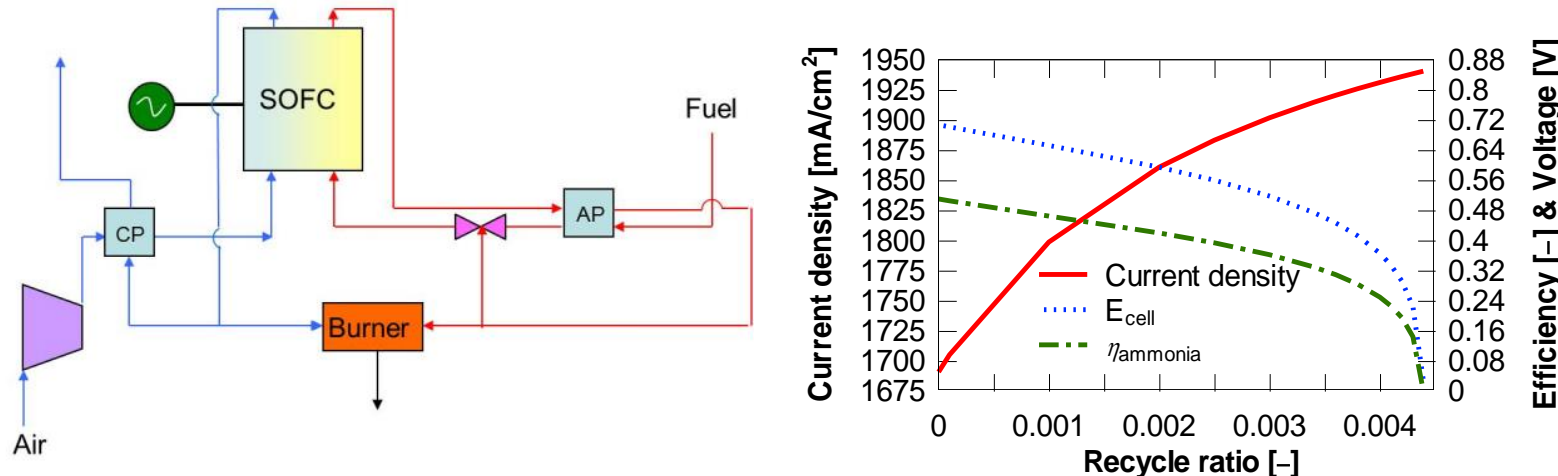

852

853

854

855

856

857

858

Figure 4. a) SOFC plant design fed by ammonia and b) effect of recycle ratio.

859 
Rokni M. Addressing Fuel Recycling in Solid Oxide Fuel Cell Systems Fed by Alternative Fuels. Energy 2017;137:1013-1025. DOI: 10.1016/j.energy.2017.03.082

860

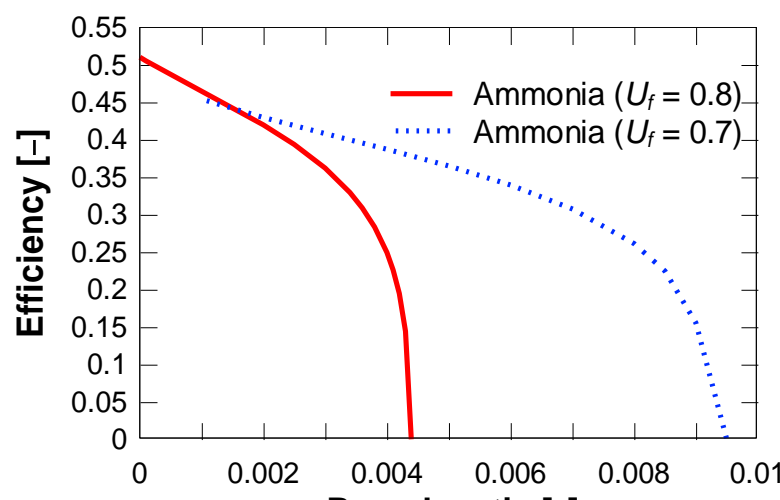

863

864

865

866

867

868

Recycle ratio [-]

869

Figure 5. Effect SOFC fuel utilization factor on plant efficiency, fed by ammonia. 
Rokni M. Addressing Fuel Recycling in Solid Oxide Fuel Cell Systems Fed by Alternative Fuels. Energy 2017;137:1013-1025. DOI: 10.1016/j.energy.2017.03.082

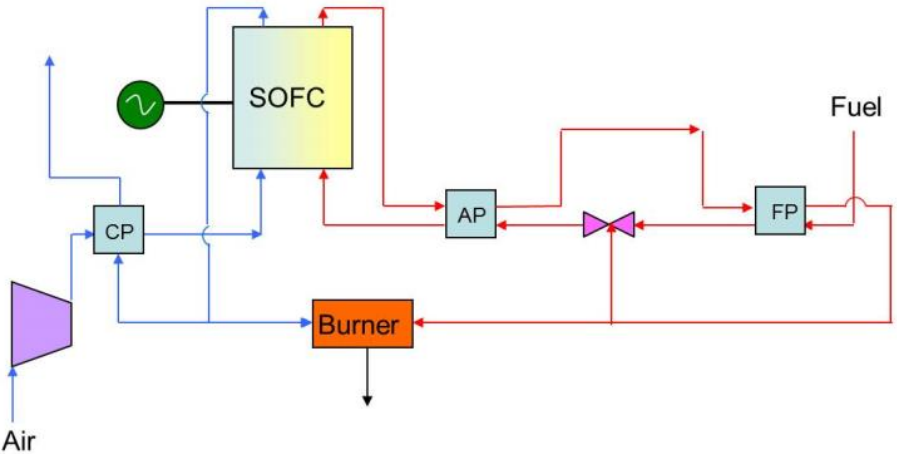


Rokni M. Addressing Fuel Recycling in Solid Oxide Fuel Cell Systems Fed by Alternative Fuels. Energy 2017;137:1013-1025. DOI: 10.1016/j.energy.2017.03.082

880

881
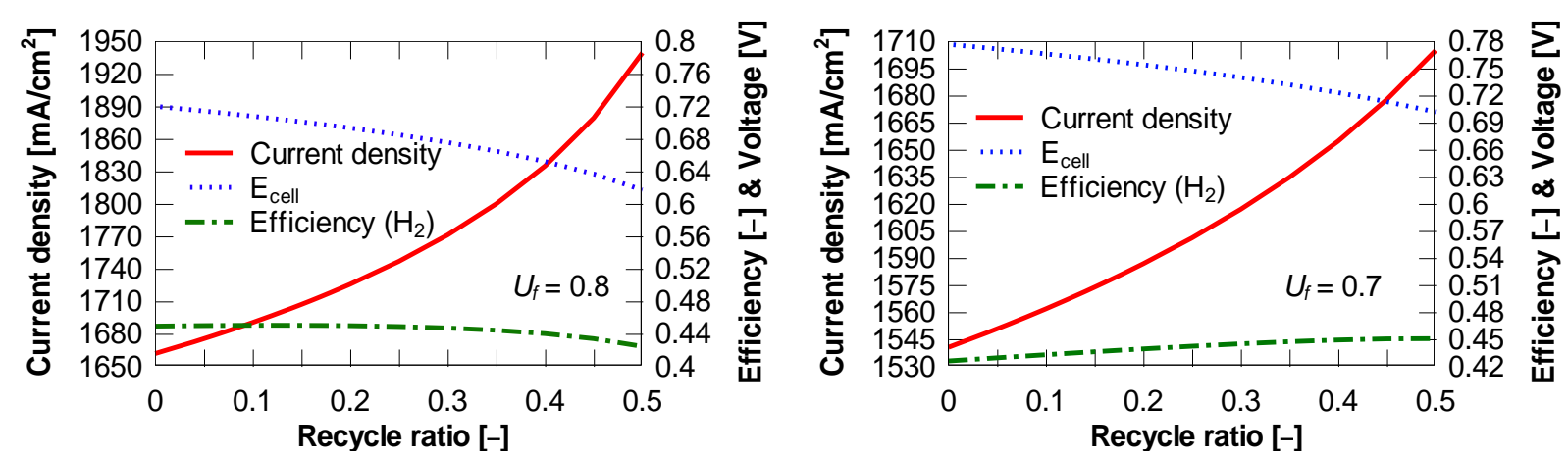

882

883

884

885

a)

b)

886

887

888

889

890

891

892

Figure 7. Effect of recycling on a SOFC plant fed by hydrogen, a) $U_{f}=0.8$ and b) $U_{f}=0.7$.

893 
Rokni M. Addressing Fuel Recycling in Solid Oxide Fuel Cell Systems Fed by Alternative Fuels. Energy 2017;137:1013-1025. DOI: 10.1016/j.energy.2017.03.082

894

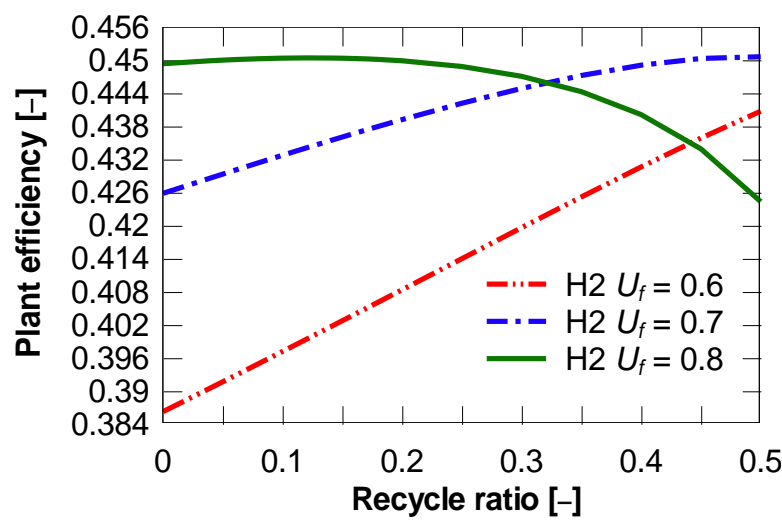

897

898

899

900

901

902

Figure 8. Effect SOFC fuel utilization factor on plant efficiency, fed by hydrogen.

903 
Rokni M. Addressing Fuel Recycling in Solid Oxide Fuel Cell Systems Fed by Alternative Fuels. Energy 2017;137:1013-1025. DOI: 10.1016/j.energy.2017.03.082

904

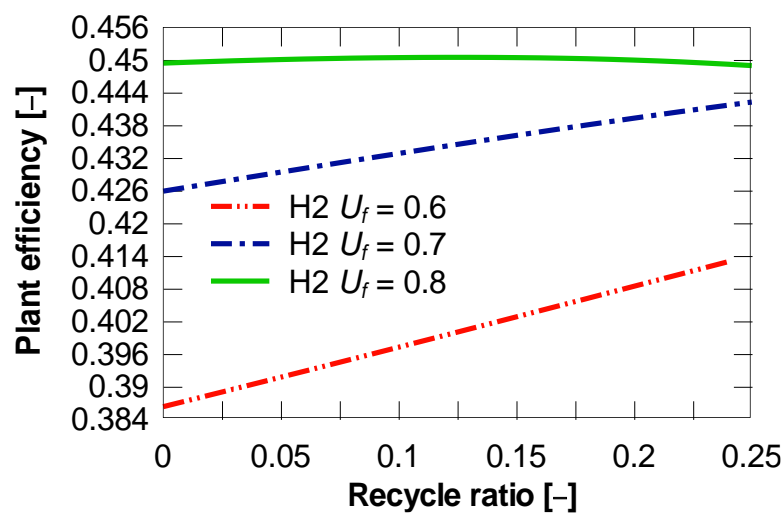


Rokni M. Addressing Fuel Recycling in Solid Oxide Fuel Cell Systems Fed by Alternative Fuels. Energy 2017;137:1013-1025. DOI: 10.1016/j.energy.2017.03.082

914

915

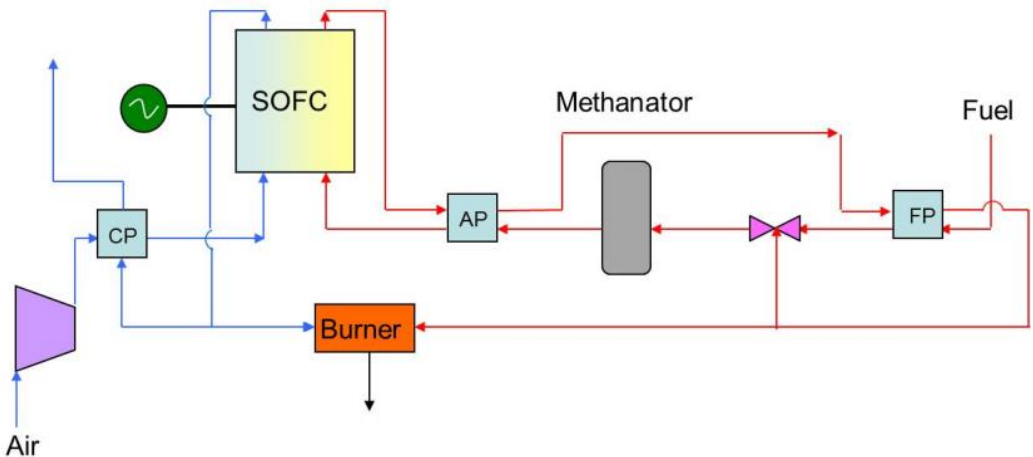

916

917

918

919

920

921

922

Figure 10. Plant design fed by methanol, ethanol and DME.

923 
Rokni M. Addressing Fuel Recycling in Solid Oxide Fuel Cell Systems Fed by Alternative Fuels. Energy 2017;137:1013-1025. DOI: 10.1016/j.energy.2017.03.082

924
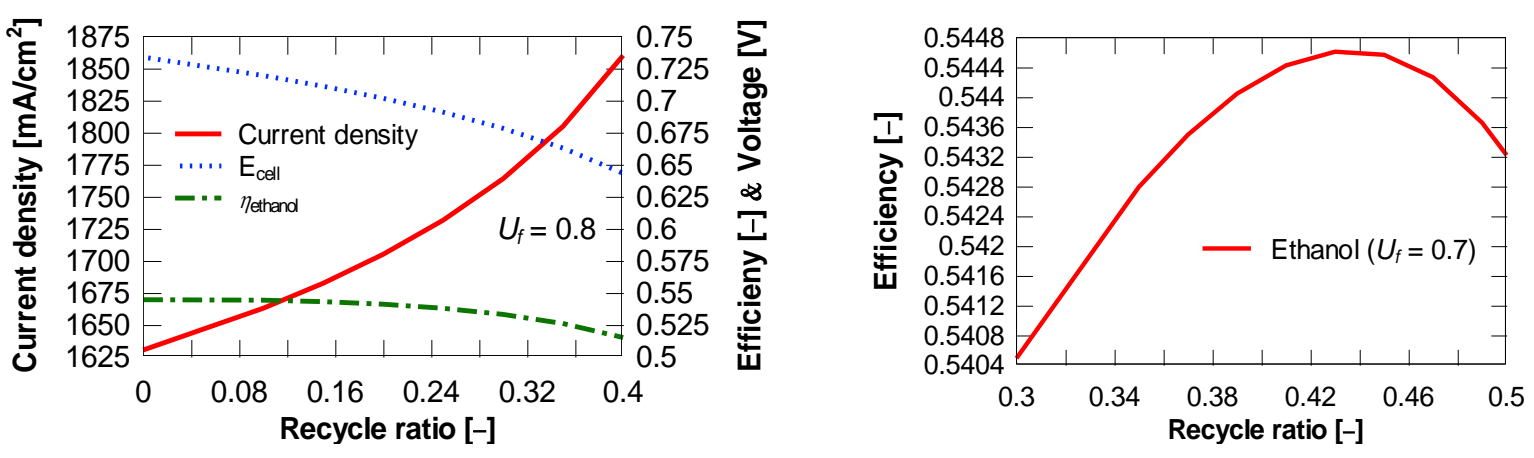

930

931

932

933

934

935

Figure 11. Effect of recycling on a SOFC plant fed by ethanol, a) $U_{f}=0.8$ and b) $U_{f}=0.7$.

936

937 
Rokni M. Addressing Fuel Recycling in Solid Oxide Fuel Cell Systems Fed by Alternative Fuels. Energy 2017;137:1013-1025. DOI: 10.1016/j.energy.2017.03.082
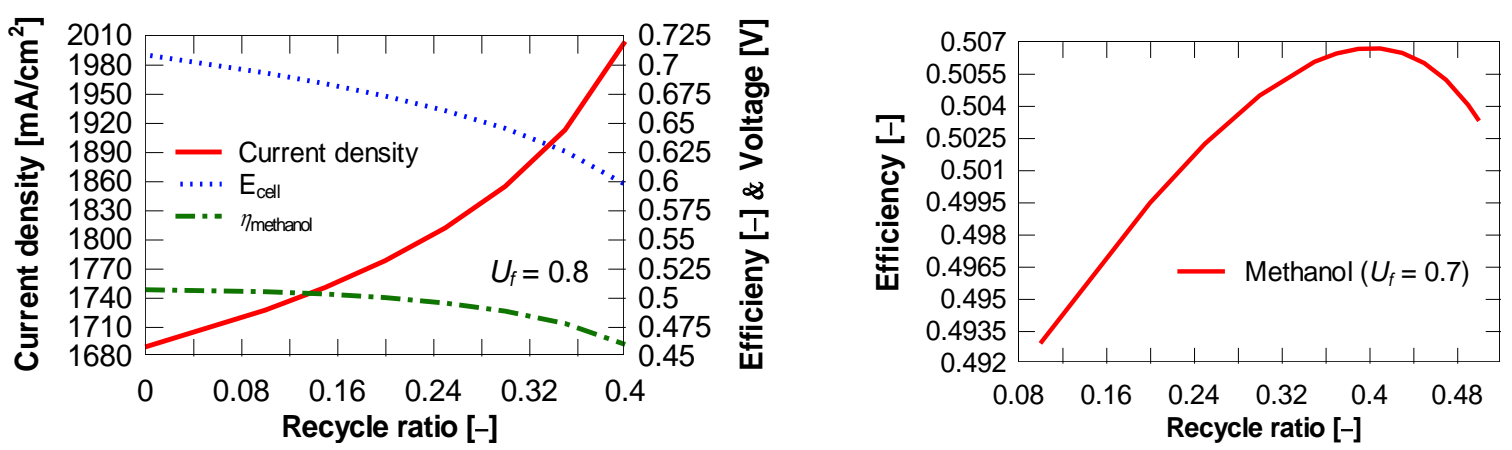

941

942

943

944

a)

b)

945

946

947

948

949

950

951

Figure 12. Effect of recycling on a SOFC plant fed by methanol, a) $U_{f}=0.8$ and b) $U_{f}=0.7$.

952 
Rokni M. Addressing Fuel Recycling in Solid Oxide Fuel Cell Systems Fed by Alternative Fuels. Energy 2017;137:1013-1025. DOI: 10.1016/j.energy.2017.03.082
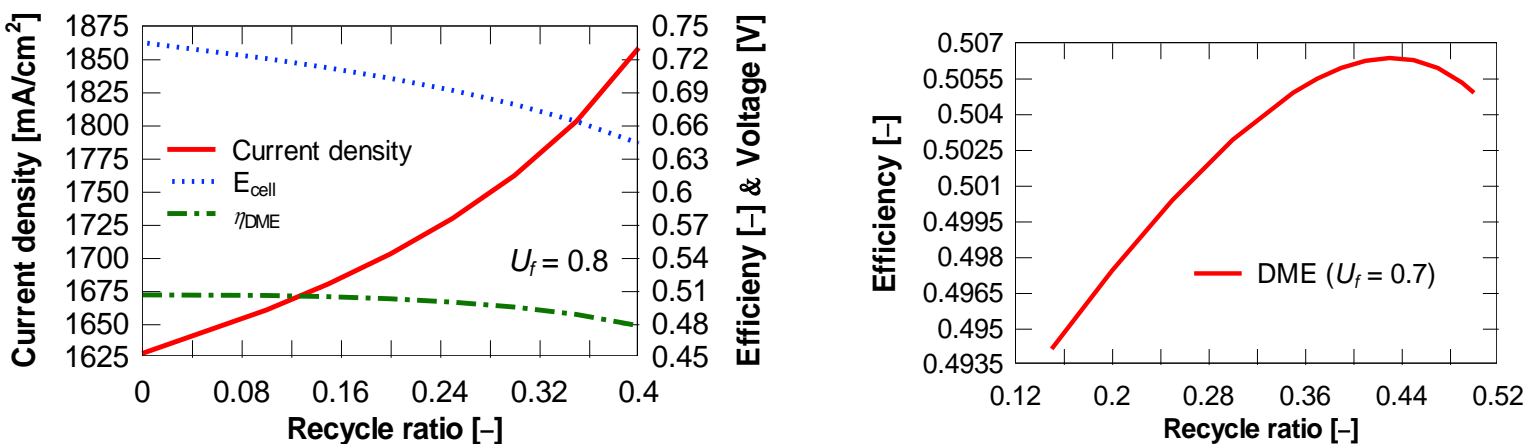
Rokni M. Addressing Fuel Recycling in Solid Oxide Fuel Cell Systems Fed by Alternative Fuels. Energy 2017;137:1013-1025. DOI: 10.1016/j.energy.2017.03.082

968

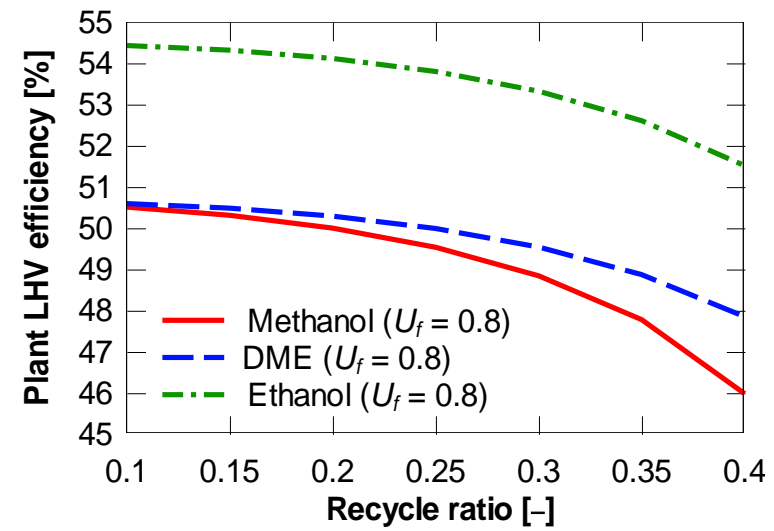

a)

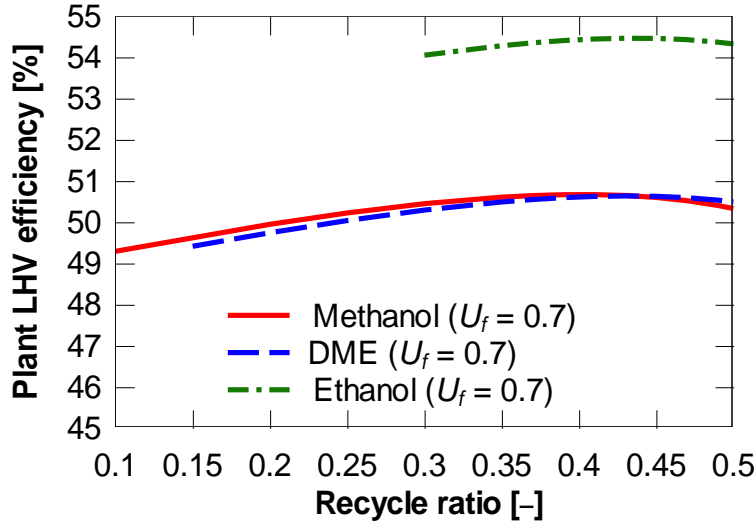

b)

974

975

976

977

978

979

980

Figure 14. Effect of recycling on a SOFC plant fed by methanol, ethanol and DME, a) $U_{f}=0.8$ and b) $U_{f}=0.7$

981

982 
Rokni M. Addressing Fuel Recycling in Solid Oxide Fuel Cell Systems Fed by Alternative Fuels. Energy 2017;137:1013-1025. DOI: 10.1016/j.energy.2017.03.082

983

984

985

986

987

988

989

990

991

992

993

994

995

996

997

998

999

1000

1001

1002

1003

1004

1005

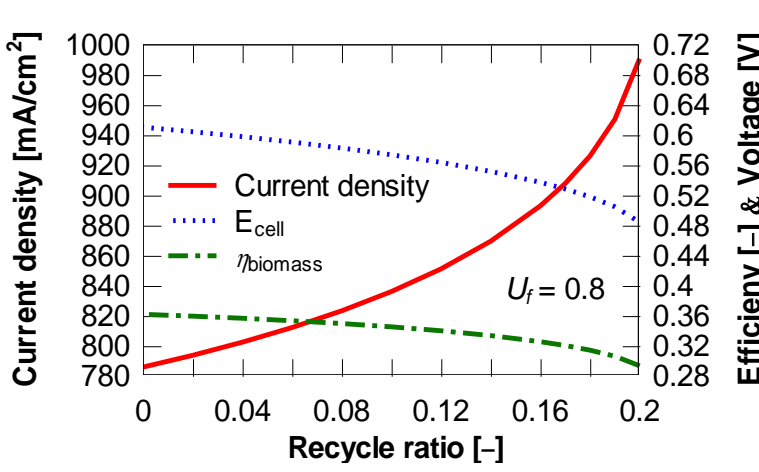

a)

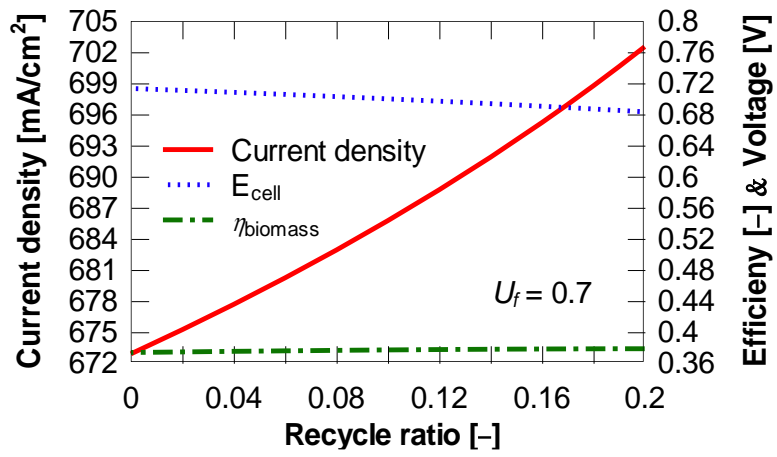

b)

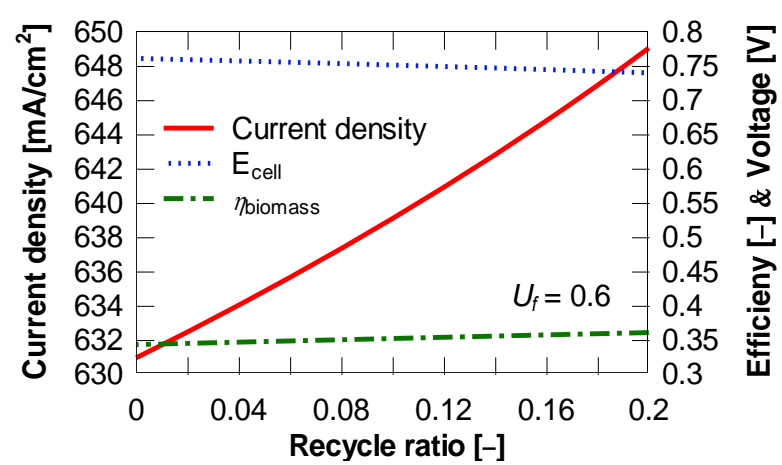

c)

Figure 15. Effect of recycling on a SOFC plant fed by biogas from biomass gasification , a) $U_{f}=$ 0.8 , b) $U_{f}=0.7$ and c) $U_{f}=0.6$. 
Rokni M. Addressing Fuel Recycling in Solid Oxide Fuel Cell Systems Fed by Alternative Fuels. Energy 2017;137:1013-1025. DOI: 10.1016/j.energy.2017.03.082

1006

1007

1008

1009

1010

1011

1012

1013

1014

1015

1016

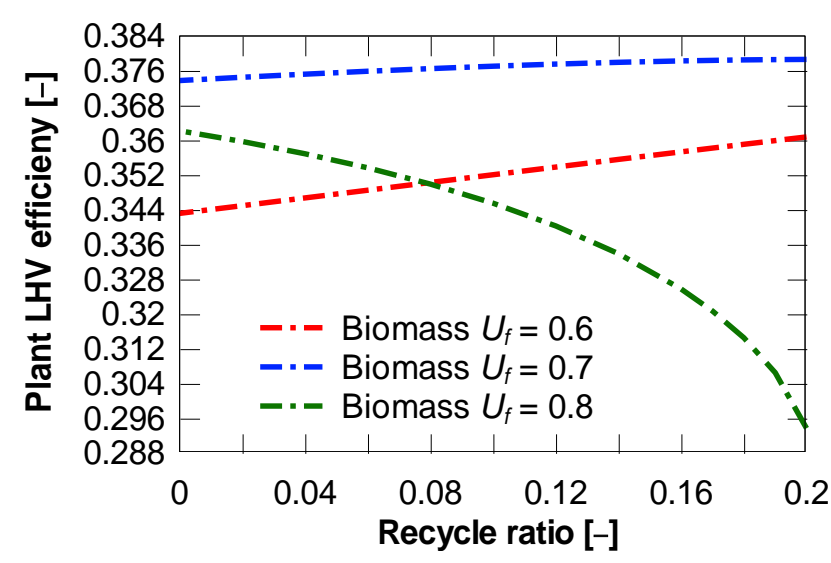

Figure 16. Effect of recycling on a SOFC plant fed by biogas from biomass gasification, a) $U_{f}=$ 0.8 and b) $U_{f}=0.6$. 
Rokni M. Addressing Fuel Recycling in Solid Oxide Fuel Cell Systems Fed by Alternative Fuels. Energy 2017;137:1013-1025. DOI: 10.1016/j.energy.2017.03.082

1017

1018

1019

1020

1021

1022

1023

1024

1025

1026

1027

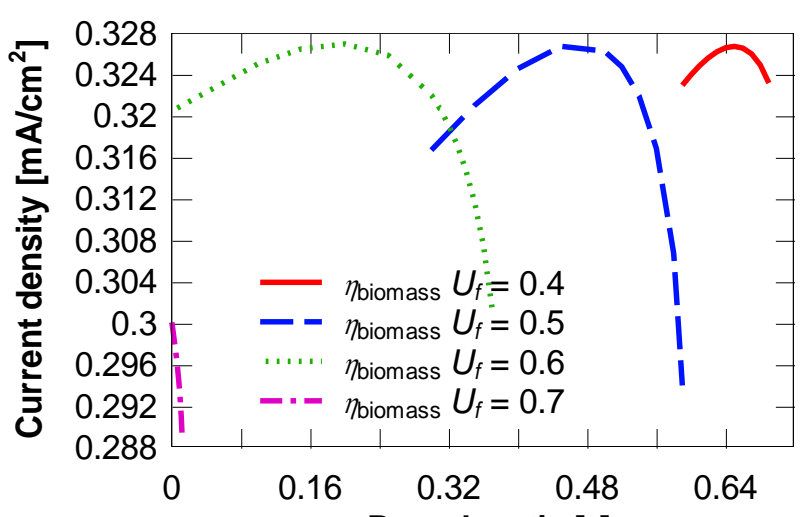

Recycle ratio [-]

Figure 17. Effect of recycling on a SOFC plant fed by biogas from biomass gasification when number of stacks is 8 . 
Rokni M. Addressing Fuel Recycling in Solid Oxide Fuel Cell Systems Fed by Alternative Fuels. Energy 2017;137:1013-1025. DOI: 10.1016/j.energy.2017.03.082

1028

1029

1030

1031

1032

1033

1034

1035

1036

1037
Table 1. The main SOFC parameters used in this study [13], [8].

\begin{tabular}{l|c}
\hline \multicolumn{1}{c|}{ Parameter } & Value \\
\hline Fuel utilization factor & 0.8 \\
Number of cells in stack & 74 \\
Number of stacks & 8 \\
Stack electricity production $(\mathrm{kW})$ & 10.2 \\
Cathode pressure drop ratio $(\mathrm{bar})$ & 0.005 \\
Anode pressure drop ratio $(\mathrm{bar})$ & 0.001 \\
Cathode inlet temperature $\left({ }^{\circ} \mathrm{C}\right)$ & 600 \\
Anode inlet temperature $\left({ }^{\circ} \mathrm{C}\right)$ & 650 \\
Outlet temperatures $\left({ }^{\circ} \mathrm{C}\right)$ & 780 \\
DC/AC convertor efficiency & 0.95 \\
\hline
\end{tabular}


Rokni M. Addressing Fuel Recycling in Solid Oxide Fuel Cell Systems Fed by Alternative Fuels. Energy 2017;137:1013-1025. DOI: 10.1016/j.energy.2017.03.082

1038

1039

1040

1041

1042

1043

1044

1045

1046
Table 2. The main parameters for the accessory components [13], [26].

\begin{tabular}{l|c}
\hline \multicolumn{1}{c|}{ Parameter } & Value \\
\hline Compressor isentropic efficiency & 0.6 \\
Compressor mechanical efficiency & 0.95 \\
Fuel side heat exchangers $\Delta \mathrm{p}($ bar $)$ & 0.001 \\
Air/Gas side heat exchangers $\Delta \mathrm{p}$ (bar) & 0.005 \\
Desulfurizer temperature $\left({ }^{\circ} \mathrm{C}\right)$ & 200 \\
Fuel inlet temperature $\left({ }^{\circ} \mathrm{C}\right)$ & 25 \\
Burner efficiency & 0.97 \\
Depleted air temperature $\left({ }^{\circ} \mathrm{C}\right)$ & 40 \\
\hline
\end{tabular}

